\title{
The Rehn-Meidner model in Sweden: its rise, challenges and survival
}

\author{
Lennart Erixon
}

(February, 2008)

Department of Economics, Stockholm University, 10691 Stockholm, Sweden

\begin{abstract}
A Swedish economic policy was developed by two trade union economists shortly after the Second World War. The Rehn-Meidner model recommends the use of selective employment policy measures, a tight macroeconomic policy and a wage policy of solidarity to combine full employment and equity with price stability and economic growth. Although never consistently applied in Sweden, it is possible to distinguish a golden age for the RehnMeidner model from the late 1950s to the early 1970s. In the 1970s and 1980s, Swedish governments abandoned the restrictive macroeconomic means of the Rehn-Meidner programme and decentralised wage bargaining obstructed the wage policy of solidarity. In the 1990s and 2000s a new economic-policy regime could not meet the strong requirement of full employment in the Rehn-Meidner model but it satisfied the model's priority of selective employment policy within the framework of a restrictive macroeconomic policy.
\end{abstract}

JEL classification: E24; E31; E62; J23; J31; J62; O23

Keywords: Swedish model; Rehn-Meidner model; third way; labour market policy; wage policy; productivity growth, fiscal policy; unemployment; inflation

Contact author: Lennart Erixon, Department of Economics, Stockholm University. Tel.: +468

1621 36; fax.: +46 81594 82; e-mail: lex@ne.su.se. 


\section{Introduction}

The Rehn-Meidner model (R-M model) is a unique Swedish contribution to macroeconomics. Two trade union economists - Gösta Rehn and Rudolf Meidner - advocated an active labour market policy, a wages policy of solidarity and a restrictive macroeconomic policy primarily indirect taxes - to combine full employment with fair wages, price stability and high economic growth. The programme was presented in a report to the 1951 congress of LO, the central organisation for blue-collar workers in Sweden (LO, 1953). Rudolf Meidner was the head of LO's research department 1946-1966 and Gösta Rehn the department's leading macroeconomist 1941-1952.

Erixon (2008) scrutinizes the efficiency of the R-M instruments and the validity of the model's underlying economic theory in light of Sweden's macroeconomic development in the post-war period. The aim of this paper is to analyse whether the R-M policy model was actually applied in Sweden until the fall of 2006. For the third time in the post-war period a social democratic government was then replaced by a centre-right coalition government. This paper also uses the R-M model as a point of reference for a description of Sweden's economic policy in the post-war period. Another purpose of this paper is to distinguish the economicstructural and political-institutional conditions, ideologies, power relations, economic paradigms and economic-policy experiences underlying the application of and also departure from the R-M model in Sweden. This analysis is more comprehensive than the corresponding account of the model in practice.

The following inquiry into Swedish economic and wage policy, with a particular eye on the R-M model, is based on official statistics and reports (including budget bills of Sweden) and on earlier work by social scientists on the practice of the "Swedish model". The paper's 
contribution to statistics is a survey of Swedish labour market policy 1965-2005 and a description of trends in profits shares in 10 OECD countries (including Sweden) 1955-2003 (see Appendix). The study is both historical and country-comparative albeit without any systematic comparison between Sweden and countries that are similar in terms of size, openness, industrial composition or political institutions.

The analysis of the application of the R-M model is not without complications. An economic and wages policy in conformity with the model does not necessarily mean that it itself has guided decision makers. Swedish politicians might have been governed by economic-policy models, in some respects similar to the R-M model. Neither do politicians' references to the model ex post prove that it really had any influence over the economic policy during the period under review. Another problem when analysing the application of the R-M model is that its fathers do not provide an unambiguous blueprint for the design of macroeconomic policy (fiscal and monetary policy) for a recession. The model was basically formulated for an overheated economy and for the medium term. However, difficulties defining the content and influence of the R-M programme have not stopped me from drawing some conclusions about its applicability in Sweden. The R-M model was never fully and consciously applied, but it is possible to speak of a "golden age" for the model from the end of the 1950s up to the first oil crisis in 1973-1974.

Section 2 presents the R-M policy programme. Section 3 outlines the application of a Keynesian economic policy in Sweden during the early post-war years. Section 4 analyses the golden age of the R-M model. Section 5 studies the period from the mid-1970s up to the deep economic crisis at the beginning of the 1990s with major external challenges to, and some obvious deviations from, the model in Sweden. Section 6 explores the status of the R-M 
model under a new economic-policy regime emphasising price stability, Central Bank independence and strict targets for monetary and fiscal policy.

\section{The essence of the Rehn-Meidner model}

A restrictive fiscal policy in the medium term (over the business cycle) was the original instrument to curb inflation in the the R-M model. Revaluation and restrictive monetary policy are other R-M measures to combat inflation. ${ }^{1}$ The aim of a restrictive macroeconomic policy in the R-M model is to prevent price increases when nominal wage growth is maintained by a selective policy of full employment (see below). Rehn and Meidner also suggested that this policy combination would have a wage-restraining effect from the corresponding squeeze on profit margins. ${ }^{2}$ High expected profits from recruiting labour and high actual profit margins lead, they argued, to widespread wage drift, i.e. to wage increases outside central agreements, in leading wage sectors; in Sweden the exposed sector has generally been wage-leading in the post-war period. Wage drift at the initiative of employers will induce compensatory demands from wage earners experiencing moderate wage drift to recapture earlier relative-wage positions.

In the R-M model a restrictive economic policy over the business cycle does not exclude countercyclical fiscal policy, or even an underbalanced public budget, in a period of low

\footnotetext{
${ }^{1}$ In the debate between him and Erik Lundberg, Rehn had first criticized the use of monetary measures in stabilisation policies. He considered the policy of permanently low rates of interest in Sweden in the early postwar period the most suitable monetary policy (Rehn, 1952a, pp. 51-2 and 1952b, pp. 75-6). But already in the 1951 LO report Rehn placed restrictive monetary policy almost on an equal footing with contractionary fiscal policy (LO, 1953, pp. 84 and 90-1, see also Rehn, 1969, pp. 164-6 and 169-70 and 1977, p. 223).

${ }^{2}$ High profit margins, Rehn and Meidner argued, would boost firms' financial capacity to bid up wages for scarce labour. They also thought that high profit margins would increase firms' willingness (and ability) to pay X-inefficient wages, thus wages above (marginal) labour productivity (Rehn, 1952a, pp. 32-43; LO, 1953 , pp. 92-3; Hansen and Rehn, 1956, p. 89; Rehn, 1969, pp. 163 and 170 and 1987, pp. 65-8; Erixon, 2000, pp. 25-9 and 2001, pp. 23-4). Rehn and Meidner maintained further, like today's efficiency-wage theorists, that higher profits accruing to firms' owners would provoke higher wage claims. However, Rehn and Meidner seldom referred, as the efficiency-wage theorists, to the risk of adverse productivity effects if employers were to reject
} 
economic activity. A reasonable interpretation of the R-M model is that it suggests a selective employment policy together with countercyclical monetary and fiscal policy including the possibility of intentional public budget deficits during a deep recession (depression). For a "normal" (or weak) recession the model recommends selective employment stimuli within the framework of a monetary and fiscal policy that is neutral or restrictive. ${ }^{3}$ The difficulty of analysing the application of the model's monetary and fiscal policy lies, of course, in deciding whether a recession has been severe or not.

The Rehn-Meidner model advocates a restrictive fiscal policy in the medium term not only to reduce inflation - this policy should also, by contributing to a decline in profit margins, alter functional income distribution in favour of labour and increase public saving at the expense of company saving. Rehn and Meidner favoured public saving on equity, and also on industrialpolicy, grounds. ${ }^{4}$ These objectives make public saving the least market-conforming component of the R-M model. Rehn and Meidner also expected that lower profit margins (reduced markups or intra-marginal profits) would stimulate total factor productivity by speeding up rationalisation and the elimination of production units with low productivity levels or low productivity growth; productivity is particularly stimulated if low-productivity firms and industries are hit by a combination of a general decline in profit margins and a wage policy of solidarity (see below).

these demands for higher wages on equity grounds (see, however, Hansen and Rehn, 1956, p. 90 and Rehn, 1987, p. 76).

${ }^{3}$ The 1951 report contains no reservations when recommending countercyclical fiscal policy - an underbalanced public budget may be necessary to keep full employment (LO, 1953, p. 91). Rehn also claimed in other works that the price stabilising effects of an overbalanced budget in the medium term would indeed increase the scope for public budget deficits. But it seems that Rehn only recommended a fiscal policy leading to public budget deficits provided that the recession is deep (see Rehn, 1952a, p. 52, 1952b, p. 76, 1969, pp. 166 and 180, 1977, p. 213 and 1982, pp. 1-3, 8, 18 and 26).

${ }^{4}$ Rehn, 1952a, pp. 36 and 51, 1952b, p. 74 and 1969, p. 165. 
In the R-M model active labour market policies including marginal employment subsidies are the main instruments to prevent unemployment from rising in the wake of a restrictive macroeconomic policy. Rehn expected that marginal employment subsidies, which he enthusiastically argued for from the 1970s, would reduce prices and also contribute to lower inflation by the subsequent squeeze of profit margins for firms that do not qualify for a subsidy. Rehn suggested that employment subsidies could be permanent and universal, thus not restricted to some groups in the labour market or to some sectors. ${ }^{5}$ In the original R-M model full employment with a high level of ambition - open unemployment at least below 3 per cent - is guaranteed by supply-side measures on the labour market (retraining, vocational education and relocation grants), matching actions (primarily public information services) and targeted demand-oriented policies to increase demand for labour in certain regions, industries and firms. In fact, these measures explain why nominal wages are rigid downwards in the model. The propensity of labour market policy to reduce wage increases by making labour markets more effective and wage earners more productive is offset by the policy's tendency to keep up wages by preventing open unemployment. ${ }^{6}$ However, in the R-M model, the subsequent decline in profit margins is a weapon in the fight against inflation.

The term "selective employment policy" is often used (e.g. in this paper) to distinguish the RM model from a Keynesian model. But the term is misleading for the marginal employment subsidies and also for the supply and adjustment (mobility-enhancing) measures of the R-M model; these measures should be universal, thus not target specific groups on the labour market, for example unemployed persons. Formulations, for example in the 1951 LO report, point to Rehn and Meidner putting greater emphasis on supply and adjustment measures (mobility-enhancing policies) than on job-creation measures (LO, 1953, pp. 92-3). Labour

\footnotetext{
${ }^{5}$ Rehn, 1982, 1987, pp. 71-2 and 1993, pp. 21-2; Erixon, 2000, pp. 27-9.
} 
market policy serves the purpose not only to guarantee low rates of open unemployment and to control inflation by keeping down profit margins; it would also reduce inflationary bottlenecks in the labour market and foster structural change. Rehn's argument for mobilityenhancing labour market policy and high ambitions in employment policy was also based on his specific notion of individual freedom. "Security of wings" would give the individual more freedom and power in relation to corporations than "security under shells", that is laws and collective agreements on job security.

A specific task of mobility-enhancing labour market policies, and also of restrictive macroeconomic policies, is to back up the wage policy of solidarity. A wage policy of solidarity through coordinated wage negotiations implies that employees with similar jobs are paid the same wage regardless of the profit situation of firms and industries. Wage differences should reflect differences in working environment and job content, for example differences in skill. In fact, solidarity wage policy is an instrument anticipating a long-run equilibrium in perfect labour markets (Rehn, 1969, p. 165). In the R-M model the wage policy of solidarity is also a "fair" instrument of economic growth. Low-productivity firms and plants that cannot bear solidarity wages must rationalise or disappear, freeing resources for the expansion of dynamic firms. ${ }^{7}$ Furthermore, in the R-M model, solidarity wage policy would play a part in the struggle against inflation. This wage policy is supposed to hold back wage increases in profitable companies willing and able to pay higher wages than solidaristic ones. Rehn and Meidner also thought that the establishment of a "rational" (fair) wage structure would mitigate inflationary wage-wage spirals, which tend to appear when unions try to increase or

\footnotetext{
${ }^{6}$ Rehn, 1952a, p. 32, 1977, p. 212 and 1982, p. 44; LO, 1953, pp. 46-9 and 99; Rehn, 1987, p. 67, see also Erixon, 2000, pp. 38-40 and 67 and Erixon, 2008.

${ }^{7}$ In the 1951 LO report the notion of rationalisation is broad, including the elimination of production slacks (the definition used throughout this paper), organisational changes, labour substitution and even the adoption of new technologies.
} 
maintain the relative wage levels of their members. However, the wage policy of solidarity leads neither to wage stability nor to structural change, if there is no restrictive fiscal policy and active labour market policy to reduce overall profits and promote labour mobility. ${ }^{8}$

Rehn and Meidner were of the opinion that their policy, aimed at restraining aggregate demand, intensifying price competition, squeezing profit margins and making labour markets more effective, was superior to a Keynesian strategy for fighting inflation in an economy approaching full employment. (I ignore here the possible inflation-dampening effects of wage policy of solidarity.) The Keynesian post-war model is connected in this paper with expansionary macroeconomic policies, primarily demand-stimulating fiscal policies and devaluations, in combination with regulation and selective fiscal measures to conquer inflation and sustain low rates of unemployment. In the Keynesian model, it is mainly incomes policy - that is, price controls and wage moderation - that was expected to improve the trade-off between inflation and unemployment. Rehn and Meidner doubted, primarily by reference to wage drift, that incomes policy could prevent high nominal wage increases in a situation where full employment is elicited by high aggregate demand. Furthermore, the Keynesian remedy for inflation is not only ineffective, Rehn and Meidner argued, but also counterproductive. Price and investment controls hurt mainly efficient firms and investment projects. In addition, wage restraint weakens the willingness of firms to rationalise, if it is at all possible for the trade union movement - which Rehn and Meidner doubted - to moderate wage demands in an overheated economy. Moreover, they feared that committments to wage moderation would generate conflicts between trade unions, between trade union leaders and

\footnotetext{
${ }^{8}$ LO, 1953, pp. 90-1 and 96; Rehn, 1952a, pp. 39-44 and 1977, p. 216.
} 
rank-and-file members and eventually also between "responsible" trade unions and governments. ${ }^{9}$

\section{Swedish economic policy before the Rehn-Meidner model}

Already at the beginning of the 1930s, a social democratic government had accepted, and partially also practised, the idea of public budget deficits in a recession. The Stockholm school, with Gunnar Myrdal and Bertil Ohlin as prominent spokesmen, contributed to the early breakthrough of Keynesian ideas in Sweden. Keynes had emphasised the need of an expansionary fiscal policy during mass unemployment. The Stockholm school provided arguments for a countercyclical economic policy in general. The ideas of Keynes and the Stockholm school had a strong influence on Swedish economic policy immediately after the Second World War. Myrdal served as an expert in the committee charged with the task of writing the post-war programme of the labour movement (Arbetarrörelsens efterkrigsprogram, 1944). The LO economist Gösta Rehn was a coordinator of the committee, and consequently one of the authors of the programme. The post-war programme was a radical child of the Keynesian revolution, showing strong similarities to the "Beveridge plan" (Beveridge, 1944). Both programmes recommended investment planning and regulation of capital and product markets (including some nationalisation) to maintain peak levels of employment. They intended to fight inflation with the help of incomes policy and other regulations - not through a strict economic policy endangering full employment (Beveridge, 1944, pp. 198-207; Arbetarrörelsens efterkrigsprogram, 1944, pp. 48-9).

The post-war programme of the Swedish labour movement was built upon expectations of a coming depression similar to the one a few years after the First World War. But the expected

\footnotetext{
${ }^{9}$ LO, 1953, pp. 81-7, see also Rehn, 1952a, pp. 36 and 48-9 and 1987, pp. 62 and 67-8; Meidner, 1952, pp. 21
} 
post-war depression did not occur. The rapid reconstruction of Western Europe was very favourable to Swedish export industries, which specialized in raw materials, semi-finished goods, and investment goods. An export boom, coupled with high domestic investments and a pent-up demand for housing and durable consumer goods, led to overheating tendencies in the Swedish economy during the second half of the 1940s and the early 1950s. Neither social democratic governments, nor the non-socialist opposition, were prepared for the problems of economic instability typical of an overheated market economy with its inherent tendency to a low rate of unemployment.

Stabilisation policy in Sweden from the end of the Second World War to the end of the 1950s showed similarities to the post-war programme of the labour movement and the Beveridge plan. Sweden, like many other Western countries, followed an economic-policy programme labelled the Keynesian post-war model in this paper. Social democratic governments made "full employment" a priority, full employment being more ambitiously defined than during the 1930s. They did not use restrictive general economic policy to counteract the tendencies towards overheating during the second half of the 1940s and first half of the $1950 \mathrm{~s} .{ }^{10}$ Fiscal policy (by general government) was countercyclical but mainly expansionary (cf Matthiesen, 1971, pp. 176-7). In fact, in 1947, with the support of the LO leadership, a social democratic government had abolished general sales taxes as a part of its stabilisation policy. Monetary policy was also expansionary until the mid-1950s. A policy of low interest rates - which was made possible through monetary regulation - led to a vast increase in liquidity in the Swedish economy.

and 25 .

${ }^{10}$ Sweden had been ruled by a broad coalition government during the Second World War. Immediately after the war, the social democrats formed a one-party government. Between 1951 and 1957, the Social Democratic party joined a coalition government together with the Farmers' party, Bondeförbundet (Centerpartiet from 1958). The 
The government revalued the krona in 1946 in order to weaken inflationary impulses from abroad. But after the revaluation, in line with the Beveridge plan and the post-war programme of the labour movement, the government undertook a series of extraordinary measures to alleviate overheating and improve the trade balance. ${ }^{11}$ It fought domestic inflationary tendencies in 1946-1948 through profit and selective purchase taxes, price controls and regulation of the construction sector. Many measures were facilitated by regulation instruments developed during the war. In 1947, the development of a large current-account deficit, due to the revaluation of the krona and the domestic-demand boom, resulted in import regulations. In the fall of 1948 , the government also managed to persuade LO to accept a "wage stop" for 1949 (in effect a prolongation of the 1948 collective agreements). An extension of the wage stop until 1950 led to increased tensions between the government and LO. These tensions culminated in September 1949 when the government devalued the krona. The Swedish devaluation was caused most immediately by the devaluation of the British pound. The krona was devalued by 30 per cent in relation to the dollar, and by $13-15$ per cent in relation to the currencies of Sweden's main competitors on the export market. Soon after the devaluation (in 1950), Sweden joined the Bretton Woods agreement from 1944, which stipulated fixed exchange rates, provided the countries were not hit by major external imbalances.

The devaluation of 1949 , in combination with a positive demand and price development for Swedish export products during the Korean War, led to a surplus in the current account and a

Social Democrat party then governed alone until 1976 when it was replaced by a non-socialist coalition government. ${ }^{11}$ Ernst Wigforss was Minister of Finance from 1932 until the summer of 1949. He was also the chairman of the
committee responsible for the post-war programme of the labour movement. 
profit boom for Swedish export industries $1950-1951 .{ }^{12}$ Sweden also experienced a wage explosion and a relatively high rate of inflation. The government attempted to check inflation through regulation of the construction industry, price controls, stricter rules of inventory valuation, profit freezes and by levying duties on investments and exports. In 1952-1953, the pace of inflation was reduced by a "mini recession" and a normalisation of export prices. But the subsequent recovery entailed overheating again in 1955-1956. For the first time during the post-war period, the Central Bank (Riksbanken) forcefully tightened monetary policy, at the same time as the government tried to mitigate overheating by imposing investment fees and by phasing out the use of free depreciation allowances for machinery and equipment.

To summarize, from the end of the Second World War to the end of the 1950s Swedish fiscal policy was countercyclical, as was monetary policy from the mid-1950s, but with a tendency to expansionism. Governments tried to cushion the inflationary effects of their economic policies, and tendencies to deficits in the current account, through regulation, including informal incomes policy, and by extraordinary fiscal measures to weaken incentives to invest, and to moderate price and wage increases in the most overheated industries. Indirect taxes, fundamental ingredients of the R-M model, were not used as a source of government incomes, with the exception of selective purchase taxes.

\section{The Golden Age of the Rehn-Meidner model}

\subsection{The breakthrough}

In the late 1940s Rehn and Meidner developed an alternative to the Keynesian post-war model revealing a growing discontent with Swedish economic policy. Throughout the hot controversy with the Social Democratic party over its economic policy in 1949-1950, the LO

\footnotetext{
${ }^{12}$ Export prices increased particularly for the raw materials industries representing more than half of Swedish
} 
leadership came to approve the new ideas of Rehn and Meidner. However, at the time of the 1951 report, the LO leadership had not yet abandoned its resistance to consumer taxes. The hesitation of LO vis-à-vis indirect taxes throughout the 1950s contributed to delaying the reintroduction of general sales taxes (Erlander, 1976, pp. 265-74). Furthermore, the role of employment offices was actually reduced in Sweden in the early 1950s (Wadensjö, 2001, pp. 7-8). The R-M model received its real political breakthrough during the second half of the 1950s. In his memoirs, the Prime Minister Tage Erlander writes that he came to advocate the R-M labour market policy at a meeting with the LO leadership in 1955 (Erlander, 1976, pp. $38-41)$.

The National Labour Market Board (AMS), founded in 1948, became the chief instrument of the expansion of Swedish labour market policy. A large-scale active labour market policy was introduced for the first time during the recession of 1957-1958. Labour market policy became even more extensive and comprehensive in the recessions of 1966-1968 and 1970-1972. What is more, active labour market policy's share of GDP and of central government expenditures showed a positive trend (even excluding regional policies) from the late 1950s until 1973; at the time of the first oil crisis, expenditure on active labour market policy measures (in relation to GDP) was higher in Sweden than in other OECD countries This period also saw, in line with the R-M model, an increasing share of Swedish expenditures on active labour market policies allocated to measures stimulating occupational and regional mobility and improving the matching capability of labour markets. The share of demand-oriented measures only increased in the recession of the early 1970 s. $^{13}$

export value during the 1940s and 1950s (Erixon, 1997, table 7). 
In accordance with the R-M principle of equal pay for similar work a radical equalisation of wages between industries (and plants) and between men and women took place in Sweden from the late 1950s to the mid-1970s. Pay equalisation between industries and plants was more far-reaching in Sweden than in other OECD countries, including other Nordic countries. $^{14}$ The adjustment of women's wages to men's wages was, however, as comprehensive in Denmark and the Netherlands as in Sweden (Ohlsson, 1980; Hibbs and Locking, 2000).

Rehn and Meidner's model yielded a strong economic-political rationale for putting major emphasis on active labour market policy and a wage policy of solidarity. There were many examples in the 1960s of union representatives on industry and local levels accepting the disappearance of jobs in stagnating low-wage industries (textile and clothing industry in particular) referring to the need for labour mobility and structural change (Meidner, 1974, p. 64). Moreover, it seems the social democratic government adhered to the general economic policy of the R-M model from the end of the 1950s until the beginning of the 1970s. Fiscal and monetary policy was still countercyclical - at least until the mid-1960s - but on average stricter than during the early post-war years. ${ }^{15}$ Fiscal policy (for the entire public sector) was only mildly expansive and even restrictive (and more restrictive) during the recessions of 1966-1968 and 1970-1972, respectively. The restrained macroeconomic policy, combined with the ambitious labour market policy, was in effect an approximative application of the RM model for "normal" recessions. ${ }^{16}$ The two recessions were in fact normal in comparison to

\footnotetext{
${ }^{13}$ See Appendix 1, Johannesson, 1981, figure 1, table 2 and A.1, Johannesson, 1991, table 1A and SOU 1993:43, diagram 5.1.

${ }^{14}$ Hibbs, 1990; Zweimuller and Barth, 1994; Hibbs and Locking, 2000. During the the previous post-war period wage gaps between industries had actually increased in Swedish manufacturing (see Lundh, 1992, p. 203).

${ }^{15}$ Matthiessen, 1971, p 176; Lindbeck, 1975, p. 104; Jonung, 1993, pp. 298-303 and 346-8; Calmfors, 1993, p. 45.
} 
those of forthcoming periods. ${ }^{17}$ In the midst of the recessions, Minister of Finance Gunnar Sträng pointed out that a Keynesian expansionary policy instead of a selective employment policy would have worsened the current account and resulted in higher inflation and thus in a deteriorating competitive position for Swedish companies. ${ }^{18}$ Sweden also refrained from devaluation of its currency during the second half of the 1960s, contrary to the policies of Great Britain, Denmark and Finland. The government tackled current-account imbalances by selective tax allowances aimed at stimulating the expansion of the export sector. ${ }^{19}$

There are additional signs that the R-M model was applied in Sweden during the 1960s and at the beginning of the 1970s. Sales taxes were reintroduced in 1961 and then replaced in 1969 by value added taxes (VAT). Public savings as a share of total savings increased markedly in Sweden, as compared to other OECD countries. Furthermore, in the 1960s and early 1970s, the gross profits share of value added in Swedish manufacturing fell considerably from the high levels of the 1950s (Erixon, 1987, pp. 45-51). In fact, between 1955 and 1972, Sweden experienced a stronger reduction in the profits share than other OECD countries (see Table 2 in Appendix). It is true that the tendency to falling profits share and profitability in Swedish manufacturing was effectively counteracted by tax relieves, in particular for large, capitalintensive enterprises. The profitability decline was reduced by almost 50 per cent considering the development of profit taxes. But the incidence of profit taxes was primarily favourable for

\footnotetext{
${ }^{16}$ Rehn praised Gunnar Sträng for having met the tendency towards increased unemployment with an active labour market policy and not with an expansionary fiscal policy (Rehn, 1977, p. 223).

${ }^{17}$ In terms of GDP growth Swedish recessions in the mid-1960s and the early 1970s were also less severe than the recessions of the interwar period and normal or weaker than those of the previous post-war period (see Edvinsson, 2005, table A).

${ }^{18}$ See Ministry of Finance, Budget Bill 1971, pp. 19-20 and Revised Budget Bill 1971, p. 11, see also Swedish Economic Association, 1968, p. 29 and 1972, p. 8.

${ }^{19}$ Finance Minister Sträng's well-known distrust of devaluations might have been influenced by the R-M model. Sträng expected that a devaluation would be met by compensatory claims from wage earners and their organisations (see Swedish Economic Association, 1968, pp. 30-1, and Lundberg, 1981, 99-102).
} 
Swedish companies during the second half of the 1950s, that is before or at the beginning of the R-M epoch. ${ }^{20}$

\subsection{Was the Rehn-Meidner model really applied?}

The Swedish social democrats can hardly be said to have used the R-M model as a compass when designing macroeconomic policy from the end of the 1950 s to the beginning of the 1970s. Fiscal policy (for the whole public sector) was, contrary to the model, mainly expansionary in spite of the construction of a large public supplementary pension (ATP) fund system from $1959 .{ }^{21}$ According to the guidelines of the R-M model, fiscal policy became too expansionary during the economic booms of 1965-1966 and 1968-1970. Fiscal and also monetary restraint to keep inflation down (and to improve the current account) were introduced too late, and as a consequence, the following recessions became unnecessarily deep (Matthiessen, 1971, pp. 205-23; Tson Söderström, 1990, p. 63-7). The large active labour market policy programme was the result of a mis-timed Keynesian "stop-go" policy rather than a strict application of the R-M model. Labour market policy was the only alternative to keep down open unemployment, considering the delayed real effects of fiscal and monetary policies. The social democratic government used arguments of a R-M type to legitimate the economic policy ex post.

The tendency to falling profit shares in manufacturing during the 1960 s and the beginning of the 1970s was not the results of a strict application of the R-M programme. ${ }^{22}$ The profit decline was considerable in Sweden, and the full employment situation probably contributed

\footnotetext{
${ }^{20}$ Södersten, 1971, pp. 324-5 and 329; Erixon, 1987, table 2.1. The tendency to a weaker profitability decline because of reductions in effective taxes also appeared in other OECD countries (Södersten and Lindberg, 1983, pp. 30-2; Erixon, 1987, pp. 52-3; Hoeller et al., 1996, table 9).

${ }^{21}$ In the mid-1950s, Rehn was a forceful agent in designing the social democratic proposal of a distributive system of public funds as buffers (Meidner, 1988).
} 
to the negative profit trend. But declining profit shares and low unemployment were international phenomena at the time, that is characteristic also in countries without a sizeable selective employment policy. The absence of a Swedish devaluation during the 1960s - which could have neutralized the tendency to reduced profit margins in the exposed sector - was not mainly due to influences from the R-M model; Sweden simply had fewer external balance problems than countries that devaluated.

The LO wage policy from the mid-1960s was not only an application of the solidarity principles of the LO report - equal wages for equal work - but also a general support for low wage groups and low wage industries. The organisation was not successful in the 1960s and 1970s in negotiating a job evaluation system for the determination of just wage differentials. ${ }^{23}$ Instead a substantial part of wage equalisation during the 1960s and 1970s, both among bluecollar and white-collar workers, followed the principle of equal wages for different jobs. ${ }^{24} \mathrm{LO}$ was of the opinion that reducing wage gaps between industries, and prioritising low wage groups, was in agreement with the demand of the R-M model for a more just wage structure.

\subsection{Favourable conditions for the Rehn-Meidner model}

The R-M model was not consistently and deliberately applied in Sweden from the end of the 1950s up to 1973-1974. But the period must still be seen as the golden era of the model considering the breakthrough of active labour market policy, the wages policy of solidarity, indirect taxes and the tendency towards reduced profit shares and increased public savings -

\footnotetext{
${ }^{22}$ According to Erik Lundberg and Assar Lindbeck the negative profit tendency during the 1960s and 1970s was partly a result of influence from the R-M model (Lundberg, 1985, p. 22; Lindbeck, 1997, pp. 1291-2). I have chosen to play down further the impact of the model on the profit decline.

${ }^{23}$ The 1951 LO report had in fact expressed scepticism against a systematic job evaluation and also argued for wage equalization between different occupations in the same manner as LO did in the 1960s (LO, 1953, pp. 978).

${ }^{24}$ Hibbs, 1990; Arai, 1994; Hibbs and Locking, 2000.
} 
important intermediate goals in the R-M model. The period was also a golden era for Sweden in terms of the model's objectives for macroeconomic policy. Sweden's growth rate or tradeoff between inflation and unemployment was not exceptional in itself but it proved consistent with radical wage equalisation (see Erixon, 2008).

The external conditions for conducting the R-M model were extremely favourable from the late 1950 s to the early 1970 s. The solidarity wages policy was facilitated by a change in the mid-1950s to coordinated wage bargaining in the LO area at the initiative of the employers' federation (SAF). Central wage negotiations were also coordinated for the public sector from 1966 and for private white-collar workers from 1970 (Bjørnson Barkbu, 2000). The wages policy of solidarity was supported in the 1960s by high labour mobility in Sweden through forces other than labour market policies, that is through high labour demand in urban areas, few double-income households, high mobility by demographic reasons (the post-war baby boom generation) and positive attitudes to regional mobility in general (cf. Nilsson, 1995). Furthermore, the wage policy of solidarity was not challenged by strong demand shocks. Moreover, public saving increased through the ATP reform and profits declined as a consequence of tougher competititive pressure on Swedish companies when international trade was liberalised. Currency regulation and other restrictions on flows of financial capital across boarders during the Bretton Woods period made it possible to use monetary policy to affect economic activity levels and profit margins. Moreover, in the late 1960s, Swedish export industries were successful and differentiated enough to prevent large current-account deficits and therefore a devaluation within the Bretton Woods system offsetting the tendency to lower profits shares. Swedish current-account deficits were also counteracted by sustainable boom conditions in other Western economies. Furthermore, the strong decline of gross profits shares in Swedish manufacturing did not speed up the large companies' 
expansion abroad. Foreign production by Swedish multinational corporations in relation to their total foreign sales decreased between $1965 / 1966$ and $1973 / 1974 .^{25}$ In the 1960 s and 1970s export and foreign production were complements rather than substitutes indicating that nearness to markets was central to satisfying foreign demand (SOU 1982:27, Ch. 6 and 7).

A long-lasting government position for the Social Democratic party was conditional for the implementation of the R-M model in the 1960s and early 1970s. One of the non-socialist parties in opposition (Centerpartiet) opposed mobility-enhancing labour market policy and all of them rejected public saving in the supplementary pension fund system and first also the introduction of consumption taxes. The appointment of Gunnar Sträng as Minister of Finance in the mid-1950s facilitated the introduction of the R-M model. Together with Bertil Olsson, new head of the AMS in 1957, Gunnar Sträng was the chief architect of the expansion of labour market policy. In the late 1950s, Sträng became a supporter of sales taxes (Erlander, 1976, p. 266). He also seems to have accepted the restrictive R-M macroeconomic policy programme. $^{26}$

The application of the R-M model was also facilitated by the strong Swedish support for state interventionism to stabilise GDP and employment; a guiding principle also for leading economists at that time (cf. Lindbeck, 1997, pp. 1274-6). The strength of state interventionism in Sweden goes at least back to the 1930s (especially the early breakthrough of Keynesian ideas). It is incorrect to say, however, that the R-M model was endorsed by Swedish

\footnotetext{
${ }^{25}$ The conclusion is drawn for a large group of multinational companies (Swedenborg et al. 1988, table 2.5; Swedenborg, 2001, fig. 4.1), for 12 large multinational companies in manufacturing (Erixon, 1988, pp. 79-81) and also for 9 large multinational companies in engineering (Erixon, 1997, p. 68 and table 11).

${ }^{26}$ Lundberg, 1981, pp. 99-101. Per Edvin Sköld, Minister of Finance 1949-1955, was decidedly hostile toward the LO report. He warned against a reduction of company profits and a weakening of the economic responsibility of the trade union movement that would threaten the full employment policy and make a compulsory incomes policy necessary. During his term as Minister of Finance Sköld also opposed indirect taxation. In 1955, when Sköld retired as Minister of Finance, Rehn and Meidner were rid of their main opponent.
} 
economists. In the late 1940s Erik Lundberg, a leading Stockholm school economist, and Bertil Ohlin, who was now the chairman of the largest non-socialist party (Folkpartiet), wanted to conquer the stabilisation-policy failures of the Keynesian post-war model with a redefinition of full employment. Although receptive to the idea of active labour market policy, Lundberg and Ohlin came to advocate a general economic policy restrictive enough to stabilize nominal wages by giving up the high ambition of unemployment rates below 3 percent. ${ }^{27}$ Lundberg's attitude to the R-M model was sympathetic but critical. His main criticism was political and ideological - major public savings and selective economic policy programmes would cause the emergence of a bureaucratic control apparatus that in the long term presented a threat to democracy. In economic terms Lundberg's main objection to the model was that it underestimated the importance of high profits, both ex ante and ex post, for private investment. Admitting the risk of financial "locking-in" effects from self-financing, Lundberg advocated deregulation and capital tax reductions to improve the functioning of the capital market. $^{28}$

The breakthrough of Rehn and Meidner's ideas in Sweden in the 1960s and early 1970s cannot be explained by the support of other economists but rather by the strong position of LO, and its economists, in the discourse of economic policy-making. The rate of unemployment was permanently low and the LO organised 77 per cent of blue-collar workers in 1960; this share rose to 86 per cent in $1974 .{ }^{29}$ Through its close ties to the social

\footnotetext{
${ }^{27}$ Lundberg and Ohlin also referred, as did in fact Rehn and Meidner at the time, to shrinking productivity in an overheated economy (Ohlin, 1949, 10-26; Lundberg, 1952a, p. 9 and 1952b, pp. 70-1).

${ }^{28}$ See Lundberg, 1952b, p. 67, 1972, pp. 480-5 and 1985, p. 19. Rehn and Meidner emphasised that profit margins must be reduced in the medium term but not in the long run and not to depression levels. They also stressed the importance of large profit differentials rather than of high profit levels in general. Labour market policies, marginal employment subsidies and solidaristic wages policy were means to promote structural change by widening profit gaps between dynamic and stagnating firms, see LO, 1953, pp. 90-4, Meidner, 1969, p. 193, Rehn, 1969, p. 157, 1977, p. 214, Rehn, 1982, p. 44 and Rehn, 1987, p. 67.
} 
democratic government and (early) participation in coordinated wage bargaining, LO had a strong impact on the scope and character of economic policy (Öhman, 1974). LO also saw, at least until the mid-1960s, solidarity wage policy and labour market policy as instruments to attain labour mobility and structural change. ${ }^{30}$ The power position and priorities of the LO should not hide, however, the uniqueness of the R-M model and the innovative role of its founders. $^{31}$

\section{The Rehn-Meidner model during the turbulent 1970s and 1980s}

\subsection{External challenges}

In the 1970s, Sweden was hit, as were other small Western European countries, by the two oil crises (OPEC I and II), subsequent forceful demand shocks and by the collapse of the Bretton Woods system (1973) leading to uncertain currency conditions. A restrictive monetary policy to reduce inflationary pressure after the two oil shocks, mainly in West Germany and the United States (at the start of the 1980s), led to a major crisis for Swedish export industries. In addition, Swedish companies met with increased competition from Japan and new industrial countries operating in the world market for ships, iron ore and steel products. Also, the specialisation of exports in raw materials, semi-finished goods and investment goods was unfavourable to Swedish manufacturing during a period with deep international recessions. Between 1973 and 1982 export growth was lower for Sweden than for all other OECD

\footnotetext{
${ }^{29}$ Kjellberg, 1983, p. 278; D’Agostino, 1987, p. 18. In an international perspective union density rates were high in Sweden for both blue-collar and white-collar workers in the 1960s and 1970s (Visser, 1992).

${ }^{30}$ The LO Congress of 1951 had sanctioned, although without any formal decision, the R-M guidelines for a new economic policy. The president of the Metal Workers' Union, Arne Geijer, had opposed the solidarity wage policy of the R-M model at the congress. But once Geijer became president of the LO in 1956 he came to personify support for the solidarity wages policy and also for the mobility-enhancing labour market policy. In the report of the LO economists to the 1961 LO Congress, "Coordinated Industrial Policy" (Samordnad näringspolitik), the focus was on structural change and economic growth, not on stabilisation policy as in the 1951 report.

${ }^{31}$ SAF was unable or unwilling to formulate any criticism of or alternative to the R-M model in the early postwar period. The organisation had taken the initiative on wage coordination as it shared the R-M fear of
} 
countries and value added growth in manufacturing only higher for Sweden than for Great Britain (OECD, Historical Statistics 1988, table 3.5 and 11.2). However, during the 1980s, Sweden would, like other Western European countries, benefit from a long-term boom in the United States.

\subsection{The Rehn-Meidner heritage}

The so-called bridging policies of 1974-1976 in Sweden were a social democratic effort to stimulate domestic demand during an international recession. It consisted mainly of a reduction of VAT in 1974, support for inventory investment and of changes to the tax structure (see the Haga agreements in Section 5.3). A centre-right, three-party, coalition government formed in 1976 continued on the Keynesian road of devaluations, instead of introducing a policy of fiscal and monetary restraint, when the Swedish deficit in the current account increased after OPEC I. ${ }^{32}$ The new government devalued the krona once in 1976 and twice (by almost 16 per cent in relation to the currencies of competing countries) in 1977.

There is no reason to place too much stress on the deviation of the bridging and devaluation policies from the R-M model. These policies were adopted in a situation of exceptional recession tendencies and current-account deficits. Swedish fiscal policy (from both the central government and the entire public sector) was in fact neutral or restrictive, and even procyclical, during the bridging policy years of 1975 and 1976. However, fiscal policy turned less restrictive and directly expansionary in 1977, that is at the trough of the Swedish

\footnotetext{
inflationary wage races in an overheated economy. In the inter-war period SAF had in fact supported the principle of equal pay for similar jobs before LO (Faxén, 1989).

32 The government in 1976 was formed by Centerpartiet, Folkpartiet and Moderata Samlingspartiet (Conservative Party). Folkpartiet formed a minority government 1978-1979. After the elections in the Autumn of 1979, the former centre-right three-party government was reestablished. In 1981 Moderata Samlingspartiet left the government. After the election in the Autumn of 1982, the social democrats recaptured all seats in the Cabinet. But they could only form a majority in Parliament through the support from Vänsterpartiet (the former Communist Party).
} 
recession. ${ }^{33}$ Irrespective of political colour, Swedish governments also carried on ambitious selective employment programmes during the second half of the 1970s and the early 1980s. Centre-right governments from 1976 embarked on selective employment policy (or rather industrial policy) by subsidizing large enterprises in mining, iron and steel and shipbuilding industries to prevent plant closures and mass lay-offs. (A centre-right government also initiated a nationalisation and reconstruction of the steel industry.) The enterprises receiving extraordinary government subsidies had been hit by a worldwide recession and increased competition from Japan and the NIC countries. Similar subsidies were paid in other countries, but they were more extensive in Sweden than in, for example, Finland and Norway (Carlsson, 1983). Between 1975 and 1983, industry subsidies amounted to 29 percent of all Swedish expenditures on selective employment policy including regional policy. ${ }^{34}$

Active labour market policy expanded during the recessions in the mid-1970s and at the beginning of the 1980s in relation to both GDP and total central government expenditures. The share of the labour force in labour market policy programmes in 1984 - 5 per cent - was a Swedish record not broken until the middle of the 1990s. ${ }^{35}$ The increased expenditure on active labour market policy in the mid-1970s was first concentrated on measures to maintain labour demand from enterprises in order to avoid dismissals, mainly support to build up inventory and subsidies to in-plant training. The proportion of another demand-oriented measure - relief work programmes (especially for youth) - increased the most, both absolutely and relatively, when unemployment rose in 1977 and in 1982-1983. But despite extensive

\footnotetext{
${ }^{33}$ See Price and Muller, 1984, table 1, Erixon, 1985, p. 18, Calmfors, 1993, figure 11, OECD Economic Outlook, December 1994, 1995 and 1998, Table 30 and 31, Frank, Ohlsson and Vredin, 1993, Figure 4, 5 and 6 and Braconier and Holden, 1999, Fig. 5.2.5. In 1974-1976, that is in the era of the Keynesian bridging policies, inflation was actually lower in Sweden than in weighted OECD and EU countries and even lower than in other small Western European countries.

${ }^{34}$ Johannesson, 1991, table 1A and 1995, table 2.1.

${ }^{35}$ See Johannesson, 1995, table 2.2 and Appendix 1.
} 
demand-oriented programmes (excluding employment subsidies throughout this paper), mobility and adjustment measures did actually increase their share of total expenditure on active labour market policy in the second half of the 1970s, see Table 1 in Appendix. ${ }^{36}$ Moreover, the fact that labour market policy became more demand-oriented during the recessions of the mid-1970s and early 1980s was no serious violation of the principle of the R-M model; the possibilities of avoiding a major increase in open unemployment through other labour market policy measures were limited.

\subsection{Departures from the Rehn-Meidner model}

Despite all, selective employment policy during the second half of the 1970s and early 1980s might have been too defensive to meet the R-M model's aims of labour mobility and structural change. This conclusion is valid for the job-protecting measures of labour market policy in the mid-1970s. The subsidies to "crisis industries" were definitely too large and lasted for too long from the perspective of the R-M model. However, the design of macroeconomic policy, particularly the expansionary fiscal and exchange-rate policy during recoveries, was the major challenge to the model from the mid-1970s. A departure from the R-M macroeconomic policy occurred already in 1973-1974 when Sweden experienced a positive demand shock without correspondence in other OECD countries. (Finland is a possible exception.) Rising international raw material prices and increased foreign demand for investment goods led to a profit boom in Swedish export industries in 1973-1974. The social democratic government did not exploit the opportunity in connection with the breakdown of the Bretton Woods system to alleviate the profit boom through a revaluation. In the mid1970s the situation with "excess profits" turned into a cost and profitability crisis. The reaction of nominal wages to the asymmetric demand shock of 1973-1974 largely explains,

\footnotetext{
${ }^{36}$ This is also true if regional policy expenditures are included in the group of demand-oriented measures, see
} 
together with low open unemployment, why the cost crisis and decline in profit shares during the following international recession became more spectacular in Sweden than in other OECD countries. The wage cost crisis (reinforced by a tardy revaluation) weakened Swedish competitiveness in terms of (relative) unit labour costs, which in turn contributed to the country's loss of market share during the second half of the 1970s.

Erik Lundberg described the wage explosion, the dramatic profitability decline and the extensive selective employment programmes in Sweden in the mid-1970s as a parody of the R-M model (Lundberg, 1985, p. 26). In fact, contemporary bridging policy was a Keynesian reaction to the R-M macroeconomic policy in the recession of the early 1970s. Swedish policy makers also met the tendencies to stagflation in the mid-1970s by incomes policy. The expectations behind the "Haga agreements" between the political parties and central labour market organisations in 1974-1975 were that the combination of increased payroll taxes (aggravating the profit crisis in the short run) and reduced income taxes for wage earners would lead to lower central wage claims. The failure of the Haga agreements to prevent a cost and profitability crisis reflected, from the R-M point of view, a too passive macroeconomic policy in the recovery 1972-1974.

The looser fiscal policy from general government (and the lack of strong counter-cyclical fiscal policy from central government) in the recovery of 1978-1980 was another break with the R-M model leading to a structural public budget deficit and a new deficit in the current account even before OPEC II. Fiscal policy was eased in spite of low real rates of interest during the 1974-1980 period of high inflation. (Like those of many other OECD countries, Swedish real long-term rates of interest were even negative during some years.) In addition,

Johannesson, 1981, table 2 and Johannesson , 1991, table 1A. 
the non-socialist government had no intention to make a priority of public saving but introduced a tax-subventioned individual saving system in 1978; in fact, back in power, the social democratic government launched a similar "Everyman's saving system" in 1984.

Fiscal policy for general government was tightened during the recession of the early 1980 s. $^{37}$ The stricter fiscal policy might have been acceptable from the R-M perspective, in particular as the policy was combined with extensive selective employment policy measures. However, it is dubitable whether fiscal restraint in the early 1980s really was in line with the R-M model during a recession shaped by OPEC II and increasing real interest rates. The rate of open unemployment in Sweden rose to 3.5 per cent in 1983, the highest rate so far in the post-war period (OECD Economic Outlook, 2000, table 21 and 22). Fiscal austerity in the early 1980s was an obvious violation of a Keynesian bridging policy for a recession. But Sweden's departure from a Keynesian economic policy was not complete. In the fall of 1981, during a substantial capital outflow from Sweden due to a deteriorated balance of payments situation, the non-socialist government devalued the krona instead of allowing the Central Bank to increase the prime interest rate. Soon after regaining government power in the fall of 1982 , the social democrats again devalued the krona. The devaluations of the early 1980s reduced the value of the krona by 26 per cent - 10 and 16 percent respectively - in relation to a basket of other currencies.

The strong devaluation by the social democrats in 1982 was offensive in the sense that Sweden's competitiveness had already been restored through the non-socialist devaluation the year before. Previous capital outflows would have needed a small social democratic devaluation only. Devaluation was the foundation of the Minister of Finance Kjell-Olof 
Feldts's "third way" to improve Sweden's current account and simultaneously increase total employment. The devaluation was combined with appeals to the social partners for wage moderation. High profits in the exposed sector were important means along the third way to bolster private investment and transfer resources to the exposed sector. Feldt's third way was a clear departure from the R-M model. The devaluations of the early 1980s led, along with a strong dollar and an international recovery, to a profit boom in Swedish export industries. Moreover, the government did not revalue the krona in the mid-1980s, in spite of obvious signs of an overheated labour market and favourable external conditions in the form of a current-account surplus. The recovery of Swedish profit shares from the mid-1970s to the late 1980s was among the strongest in the OECD area (see Table 2 in Appendix).

Swedish fiscal policy was predominantly countercyclical during the boom of the 1980 s - the structural public budget deficit was eliminated 1987 - but not enough to counteract the strong tendency to overheating. ${ }^{38}$ The social democratic government tried to check inflation through price controls, and by appealing for wage restraint. In the middle of the decade, the parties on the labour market agreed to set a ceiling for wage increases through the so-called "Rosenbad rounds". (Rosenbad is the name of the government office.) However, the pace of the wage increases was to break through the ceiling. When the boom reached its peak in 1990, the LO leadership (and the Metal Workers' Union) also accepted a price, wage and strike stop. But the "stop package" did not get majority support in Parliament, which in turn led to a government crisis and the resignation of the Minister of Finance, Kjell-Olof Feldt.

\footnotetext{
${ }^{37}$ Fiscal policy for central government was clearly expansive first in 1982. See Price and Muller, 1984, table 1, Calmfors, 1993, Figure 11, OECD Economic Outlook, December 1994, 1995 and 1998, Table 30 and 31, Frank, Ohlsson and Vredin, 1993, Figure 5-6 and Braconier and Holden, 1999, fig. 5.2.5 and 5.3.4.

${ }^{38}$ With some annual exceptions fiscal policy was tightened during the boom of the 1980s, both for the central government (see Calmfors, 1993, figure 11 and Frank, Ohlsson and Vredin, 1993, figure 4, 5 and 6) and for the consolidated public sector (OECD Economic Outlook June 1996, 1998 and 2000, table 31 and June 2005, table 30; Braconier and Holden, 1999, table 5.2.5).
} 
Swedish stabilisation policy deviated from the R-M model during the second half of the 1980s. It was based on an incorrect combination of measures, if the model is to be interpreted strictly. The social democratic government fought inflation by incomes policy deals instead of through the introduction of restrictive fiscal measures and hard currency policies. Continued low unemployment was elicited by high aggregate demand, not through substantial selective employment programmes. The R-M model was followed during the second half of the 1980s in the sense that training replaced demand-oriented programmes as the most important labour market policy measure. ${ }^{39}$ In fact, from 1985 until 2005, supply and matching oriented measures were the most important components of Swedish labour market policy (see Appendix 1). Furthermore, a fall in the active labour market policy share of GDP (and the share of the labour force participating in AMS measures) from the mid-1980s largely reflected improved labour-market conditions. But the dismantling of labour market policy in the second half of the decade was probably too drastic to satisfy the R-M model's stipulation of preventing labour bottle-necks in a severely overheated economy.

There were other departures from the R-M model in the 1980s. A radical wage equalisation had occurred during the first half of the 1970s, but from the middle of the 1980s wage differences were allowed to increase substantially in the LO/SAF area. ${ }^{40}$ Wage gaps widened, not only between wage earners with different qualifications and jobs inside industries (and plants), but also between wage earners with equal jobs in different industries (and plants) - an obvious violation of the solidarity policy of the 1951 LO report.

\footnotetext{
39 This reorientation of labour-market policy was obvious in terms of expenditures and also in terms of programme participants if measures for disabled persons are ignored (Appendix 1; Johannesson, 1995, table 2.1 and 2.2; Calmfors, 1993, pp. 28-9; Johannesson, 1991, table 1 A and 1995, table 2.1 and 2.2; Ackum Agell, 1995 , figure 2.
} 


\section{Why did Sweden depart from the Rehn-Meidner model?}

Both social democratic and centre-right governments pursued an active labour market policy to prevent open mass unemployment during the recessions of the mid-1970s and the early 1980s. However, subsidies to industries in crisis, and possibly also some labour-market policy measures, broke with the principle of structural change in the R-M model. Moreover, tighter fiscal policy after OPEC II than after OPEC I was a possible challenge to the strong prioritisation of full employment in the model. But more obvious, Swedish macroeconomic policy was, according to the yardstick of the R-M model, on average too expansionary in the 1970s and 1980s, contributing to negative financial saving for the public sector from the late 1970s. Finally, widening wage gaps between workers with similar jobs from the mid-1980s was a break with the R-M model.

Strong external shocks (including fiercer competition from Japan and NIC-countries) made it more difficult to apply the economic-policy programme of the R-M model through the 1970s and 1980s. The possibility of stagflation because of supply shocks (see OPEC I and II) was not accounted for in the model. Moreover, deep international recessions gave labour market policy a more prominent role, and also a more demand-oriented profile, in the mid-1970s and early 1980s than in the original model designed for an economy with "islands of unemployment" (Rehn, 1952a, p. 34). However, external shocks cannot in themselves explain departures from the R-M model in Sweden during the 1970s and 1980s.

In the mid-1960s, LO began to prioritise job security, work environment, worker participation and collective ownership rather than labour mobility and structural change. During the following decade LO induced the social democratic government to legislate on co-

\footnotetext{
${ }^{40}$ Hibbs, 1990; Hibbs and Locking, 2000; Holmlund, 1997; Arai, 1999.
} 
determination, work environment and also on job protection, the Job Security Act of 1974. Job protection measures in labour market policy and subsidies to companies in stagnating industries during the second half of the 1970s displayed the ideological hegemony of LO. But they also reflected the shift of priorities within the organisation, and the Swedish society at large, violating the goal of structural change and perhaps also the principle of employment security - in contrast to job security - in the R-M model.

A disappointment cycle provides a plausible explanation of changes in Swedish macroeconomic policy in the 1970s and 1980s. The adoption of new means in economic policy was based on discouraging experiences of economic policy in the past. In the mid1970s, the general attitude of politicians and economists was that domestic demand had been too low during the previous recession. The bridging policies, recommended by the OECD, were largely a Keynesian reaction to the R-M policy during the recession at the beginning of the decade. (However a similar bridging policy was conceived in Denmark and Norway.) A new consensus was then established around 1980s maintaining that the overbridging policy made a significant contribution to Swedish inflation and marked the beginning of a period with current-account and public-budget deficits. The structural public deficit - a new phenomenon in Swedish economic history - largely explains why a bridging policy was not pursued in Sweden after OPEC II as after OPEC I.

However the switch of economic policy in the early 1980s cannot be understood without references to new economic thinking. Non-socialist economic advisors were governed by the rebirth of "pre-Keynesian" ideas of crowding-out as an effect of a large public budget-deficit and public sector. They were also influenced by supply-side economics giving priority to (marginal) tax reductions, wider wage differentials and deregulation rather than to (domestic) 
demand management. The main document of this new economic thinking was the Medium Term Survey presented in 1980. Also social democratic experts began to use crowding-out and supply-side arguments in the early 1980s further reducing the support for domesticdemand stimuli to achieve full employment (Bergström, 1987, pp. 94-7 and 103-4). Among other things they recommended restrictive fiscal policies along the third way to reduce the public budget deficit. The Ministry of Finance also emphasised, as did influential academic economists at that time, the necessity of reducing inflation expectations, thus initiating a critique of Swedish "accommodation policies" (Ministry of Finance, Revised Budget Bill, 1983, appendix 1, pp. 1-14). The critique was first directed against domestic demand management but soon also against new devaluations. Immediately after the devaluation in 1982, Finance Minister Feldt and other representatives of the social democratic government found it urgent to inform the parties on the labour market that compensatory nominal wage increases would not be corrected by expansionary fiscal measures or by new devaluations (Lindvall, 2004, p. 126). New economic thinking in the 1970s and 1980s affected the interpretation of past developments and assessment of earlier economic policy actions. However, the evaluation of older economic policy strategies was not always based on an undisputable analysis of underlying causal mechanisms. For example, the magnitude and negative effects of the Keynesian bridging policy in the mid-1970s were largely exaggerated (see above).

Economic-policy experiences and arguments about public crowding out in the early 1980s primarily hit the Keynesian post-war model, not the R-M model recommending a restrictive macroeconomic policy in the medium term. In fact, economists associated with the nonsocialist government began reviewing the R-M economic policy during the early 1970s recession as an ideal (Jakobsson and Herin, 1981, pp. 48-50). Moreover supply-side 
economics were either compatible with the market-conforming R-M model or critical to other features of the "Swedish model", for example wage compression in general and progressive taxes. ${ }^{41}$ The Swedish disappointment cycle provided, however, a serious challenge to the R-M model in the early 1980s. In the mid-1970s indications of a decline in the long-run profits share and profitability in the business sector were seen by Erik Lundberg, but also by other leading Swedish economists, as the main source of falling investment ratios in Sweden (Lindbeck, 1975, pp. 234-9 and 1976, p. 124). In the early 1980s, Swedish politicians and their experts were stunned by the deep cost and profitability crisis in the middle of the 1970s which they blamed for the subsequent decline in private investment and losses of Swedish markets shares. This hypothesis was not anchored in macroeconomics to the same extent as that about the shortcomings of Keynesianism. In fact, actual profits, relative prices and unit (labour) costs had a peripheral, ad-hoc, position in contemporary macroeconomics. Furthermore, the unique character of the Swedish cost and profitability crises and the negative effects of higher unit labour costs on Swedish market shares were probably overstated in the Swedish economic-policy debate (Erixon, 1985, pp. 14 and 27-30 and 1989, pp. 183-92). Nevertheless, a new consensus developed among Swedish politicians and their economic advisors insisting that low inflation was a necessary condition for full employment and that wage earners and companies, by low wage claims and relative prices, should take responsibility for employment in the short run. ${ }^{42}$ Moreover information about Sweden's (relative) wage and profit development and a "conventional wisdom" among economists and politicians about the origin of the country's industrial stagnation largely explain, together with a structural fiscal deficit, a current-account deficit and the continuing priority of full employment, why the social democrats opted for a strong devaluation in 1982.

\footnotetext{
${ }^{41}$ In 1981 Swedish marginal taxes were modestly reduced through an agreement between two parties in the nonsocialist government (Folkpartiet and Centerpartiet) and the social democrats (the "Wonderful Night").

${ }^{42}$ Medium Term Survey 1980, pp. 127-8; Ministry of Finance, Revised Budget Bill, 1983, appendix 1, p. 11.
} 
Swedish deviations from the R-M model, and also from Keynesianism, in the early 1980s were facilitated by the replacement of Gunnar Sträng by Kjell-Olof Feldt as the main spokesman of social democratic economic policy. ${ }^{43}$ Furthermore, these deviations are partly explained by a shift in power relations. In the 1970s and 1980s the Ministry of Finance had gradually increased its influence over Swedish economic policy at the expense of other ministries, political parties, Parliament and labour market organisations. Before the 1982 election, the Social Democratic party in opposition had advocated extensive public infrastructural investments and housing programmes to reduce unemployment. In power, the party was persuaded by its economic advisors, recruited from and now employed again by the Ministry of Finance, to abandon this Keynesian policy. ${ }^{44}$ However a stronger position for experts in the Ministry of Finance cannot explain the social democratic economic policy without reference to the growing doubts about Keynesianism among economists. The third way reflected a lingering influence from the Keynesian post-war model - devaluation and incomes policy - but also a challenge to domestic-demand management in economics.

Furthermore, the political and ideological influence of LO gradually deteriorated in the 1970s and 1980s. The defeat of the social democrats in the 1976 was only a temporary draw-back for LO. More decisive was the LO proposal of wage earner funds the same year, built on a report by Meidner to the LO Congress 1976 advocating collective profit sharing. The aim of wage earner funds was to change wealth distribution and power relations in favour of labour and also to appropriate excess profits as a result of the wages policy of solidarity - the most profitable firms could have paid higher wages than the solidaristic wages. Wage earner funds were supported, albeit more and more reluctantly, by the social democrat leadership. The

\footnotetext{
${ }^{43}$ Bergström, 1987, p. 196; Lundberg, 1981, pp. 101-2 and 111-2.
} 
funds became a political burden for the party in the 1976 election and also, notwithstanding a modification of the original LO proposal, in the 1979 election. A decision in Parliament in 1983 to introduce a watered-downed system of wage-earner funds developed by the social democratic government marks the end of a period in which the LO had maintained an exceptional position as an initiator of Swedish economic policy. (The funds were abolished by a non-socialist government in 1994.) LO on the defensive sanctioned the social democratic devaluation in 1982 arguing for higher profits to overcome the industrial crisis (Bergström, 1987, pp. 99-101). In the middle of the 1980s LO economists recommended a revaluation of the krona (LO, 1984, 26-7 and 137-8). However they then supported the Keynesian post-war strategy by ardently opposing the government's ambition to restrict domestic demand, arguing for selective fiscal measures to cool overheated sectors, and by accepting continual devaluations or flexible exchange rates as the last resort to sustain full employment. LO's growing resistance to fiscal austerity, but also to wage moderation (when stock markets were booming), deregulation of credit markets, proposals of limited increases in unemployment benefits only and marginal tax reductions (proposed and actual), triggered a "war of roses" between LO and the social democrat government in the middle of the 1980s. By referring to globalisation, LO economists also began to openly criticize the R-M profit squeezing policy for being out of date (LO-tidningen, 1989).

The unique position of LO in economic-policy and wage formation was weakened in the 1970s by the growth of white-collar worker organisations. The LO share of total union members in Sweden was 74 per cent in 1960. This share then decreased steadily, to 63 per cent in 1975 and to 58 per cent in 1990 (Kjellberg, 2000, table 16.1). White-collar worker organisations had no direct ties to any political party and there was no pressure on them to

\footnotetext{
${ }^{44}$ Bergström, 1987, pp. 90, 94, 109-12, 119-123, 126-7, 193-94 and 198; Lindvall, 2004, pp. 74-85 and 94-100.
} 
practice or envisage a unique "Swedish model" of economic policy. SAF's position had also been strengthened at the expense of LO's, for example through an ideological offensive starting in the late 1970s. SAF was successful in raising public resistance to wage earner funds and also in using the fund issue to unify fractions within the private business sector supporting either coordinated or industrial wage negotiations (Viktorov, 2006, ch. 6).

A reasonable argument is that labour strength and also the R-M model's value as a guide for economic-policy making was reduced in the 1970s and 1980s through globalisation. Countries following the profits-squeezing recommendations of the R-M model might have risked capital flight and relocation of production to other countries. Globalisation of financial markets and enterprises had indubitably reduced the efficiency of national economic policy aimed at reducing industrial profit margins. During the second half of the 1970s and the 1980s, foreign production by Swedish multinational companies increased as a ratio of their total sale and also of their total foreign sales. ${ }^{45}$ Foreign investment by Swedish multinationals might have produced a rival relation between foreign and domestic units, for instance where sales to third countries are concerned, making Swedish production and employment increasingly vulnerable to unit cost and profit differentials (cf. Erixon, 1997, pp. 77-8). However, larger foreign production by Swedish multinationals as a consequence of higher unit labour costs in Sweden was no major explanation of the country's loss of market share during the second half of the 1970s. Moreover, there was no increase in third-country sales for an aggregate of Swedish multinational companies from 1974 to 1978 (SOU 1982: 27, pp. 240-52). Neither is there any evidence for the 1965-1994 period that foreign production by Swedish multinational companies had curtailed exports from Sweden (Swedenborg, 2001). ${ }^{46}$

\footnotetext{
${ }^{45}$ See Erixon, 1988, p. 81, Swedenborg et al., 1988, table 2.5, Ekholm and Hesselman, 2000, table 6 and figure 4 and Swedenborg, 2001, fig. 4.1.
} 
Swedish departures from the R-M model in the 1970s and 1980s are perhaps better explained by political-institutional than by economic-structural changes. The change to a non-socialist government in the mid-1970s marked the beginning of a period until the late 1990s of government subsidies to public saving. Furthermore Swedish deviations from the macroeconomic policy of the R-M model are explained by a shift of exchange-rate regime. Sweden had first participated in the European currency cooperation after the collapse of the Bretton Woods system, and then (in 1977) built its own system of fixed exchange rates. The value of the krona was decided in relation to a basket of currencies, in which every currency reflected the importance of the country as a competitor to Sweden. The new Swedish exchange-rate system increased opportunities to stimulate the economy by devaluations. This system is also one explanation of why overheating of the Swedish economy took on new proportions during the second half of the 1980s. The fact that the dollar was assigned more weight in Sweden's currency basket than the US share of Swedish trade contributed to overheating. The competitiveness and profits of Swedish manufacturing were maintained during the second half of the 1980 s by the krona losing its value concurrently with the weakening of the dollar.

Another political-institutional change - a deregulation of the credit market - was a major factor behind Swedish overheating in the second half of the 1980s. An instant dismantling of monetary-policy instruments in the mid-1980s led, under the existing tax system, to a creditfinanced consumption, construction and stock-market boom. Credit deregulation was not

\footnotetext{
${ }^{46}$ Furthermore, a criticism that globalisation of companies and finance markets makes the R-M model out of date must be qualified, as the model recommends supply and adjustment oriented measures on product and labour markets, together with restrictive general economic policies, to fight inflation. Marginal employment subsidies, for instance, could persuade global enterprises to invest in a given country in spite of falling profit margins on average. Moreover, the consumption taxes of the R-M model are not as vulnerable to global tax competition as individual and corporate income taxes (Scharpf, 2000).
} 
preceeded or immediately followed by the abolition of a distorted tax system favouring borrowing during inflation. Furthermore deregulation was facilitated by the fact that economic experts from the Ministry of Finance were represented in the Central Bank's governing board at the time (Lindvall, 2004, p. 78). The possibilities of using monetary policy measures to affect the real economy were also limited due to the exchange-rate system policy of maintaining the value of the krona on an ever more globalised currency market. Moreover, a dismantling of Swedish capital controls had begun in the 1970s. And the efficiency of rationing instruments in Swedish monetary policy had been reduced in the 1970s and 1980s by the establishment of new financial institutions not embraced by credit controls. At the same time, lingering currency restrictions, not abandoned until 1989, accentuated overheating tendencies in Sweden by restricting investment abroad.

The dismantling of monetary policy in the mid-1980s, reducing the range of stabilisation policy measures was, however, no decisive challenge to the R-M model (or even to the Keynesian post-war model of stabilisation) in an economy with fixed exchange-rates. Why Swedish fiscal policy and exchange-rate policy was not restrictive enough during overheated conditions in the second half of the 1980s still needs to be explained. The passive fiscal and exchange-rate policy policy largely reflected economic-policy failures and political businesscycle behaviour. Contractionary measures were postponed by statistical lags but also by the psychology of politics - leading social democrats were blinded by the fact that the third way, as late as 1989, was celebrated as a success, both in Sweden and internationally (OECD, 1987; Feldt, 1991, pp. 279-80, 317, 358 and 370). Moreover, fiscal restraint was avoided by the social democrats before the 1988 election. (Analogously, a non-socialist government had pursued an expansionary fiscal policy before the 1979 election.) The passive stabilisation policy during the second half of the 1980s also reflected leading social democratic politicans 
eventual sharing of the growing scepticism in macroeconomics about fine tuning, an essential part of the challenge to Keynesianism in economics since the 1970s (Feldt, 1991, pp. 252-53).

Wider wage gaps in Sweden from the mid-1980s also largely followed a departure from coordinated central wage negotiations for both white-collar and blue-collar workers. Central wage agreements have been industry-specific since 1983 even though LO often succeeded to coordinate wage demands of blue-collar trade unions and negotiations were occasionally coordinated during the second half of the 1980s (see also the Rehnberg commission in next section). The departure from central wage coordination was initiated by SAF but supported by the Metal Workers' Union. The devaluations contributed to the decision of the union in 1983 to withdraw from coordinated LO-SAF negotiations. The union, organising the best-paid blue-collar workers in manufacturing, regarded wage coordination as a straitjacket in a situation of great opportunities for wage increases. Its members had been disfavoured by wage compression within blue-collar and white-collar worker groups respectively. In the 1970s and early 1980s, wage differences between low-paid white-collar workers and highpaid blue-collar workers in the private sector were relatively stable (Hibbs, 1990, pp. 186-8). Thus the decision of the Metal Workers' union to abandon central wage coordination in the mid-1980s largely reflected the practice of the wage policy of solidarity - a policy of general wage compression had not embraced both blue-collar and white-collar organisations.

The decision by SAF to abandon central wage coordination was initiated by the engineering industries, particularly the automobile industry, despite the fact that these industries had been favoured by the policy of equal wage for similar jobs. Some social researchers saw the new wage policy of SAF as evidence that decentralised bargaining was more rational under the third industrial revolution of flexible specialisation and new information technologies 
(Swenson and Pontusson, 2000). However, standardised production processes were still important in Swedish manufacturing, not least through continued globalisation enlarging the companies' foreign markets. Moreover, from the late 1970s, there was no uniform tendency towards decentralised bargaining in OECD countries. Neither was there any general tendency in the 1990s and 2000s towards more decentralisation within countries (such as Sweden) specialising in ICT products. ${ }^{47}$ The growing resistance to coordinated wage bargaining and wage policy of solidarity among large engineering companies in the 1970s and 1980s might partly have reflected a new technological paradigm; but increasing labour shortages in manufacturing strengthened the large engineering companies' incentives to bid for scarce (skilled) workers, while globalisation of production made large engineering companies less concerned about domestic wage-wage spirals. In addition, stronger preference for decentralised wage bargaining among engineering companies might have reflected a growing resistance to general wage compression, a salient feature of Swedish wage policy from the mid-1960s.

\section{Sweden's road from full employment}

\subsection{Depression and a new economic-policy regime}

At the start of the 1990s, Sweden experienced an economic crisis without precedent in the earlier postwar period nor a counterpart in other OECD countries at that time, save Finland. Swedish GDP growth was negative during three years, 1991-1993. The recession was even longer and deeper in terms of GDP growth than the recession in the early 1930s and the employment decline was more dramatic in the early 1990s than during any other recession in the history of Swedish industrialism (Edvinsson, 2005, table 9.7 and 9.12). Labour force participation rates fell drastically in Sweden from 1990 to 1993. Furthermore, standardised

\footnotetext{
${ }^{47}$ Nickell et al, 2005; Baker et al, 2005, see also Martin, 2000 and Wallerstein and Golden, 2000.
} 
open unemployment increased from 1.7 percent in 1990 to 9 percent in 1993, only one percentage point below the EU average. Thus Sweden entered the road to mass unemployment as other OECD countries had done in the two preceding decades.

The deep economic crisis in Sweden at the start of the 1990s was to a great extent a consequence of domestic overheating in the 1980s. In particular, enterprises in construction and service sectors, including real estate and financial services, had made very substantial investments during the credit boom of the 1980s. They were now facing reduced demand growth and falling stock market and real estate prices, e.g. as a consequence of increasing interest rates. Many enterprises, having borrowed to finance their expansion during the 1980s, had difficulties paying interest on loans, leading to bankruptcies and a very serious banking crisis. Furthermore, increased real interests and repayment of loans contributed to an increase in household savings during the first half of the 1990s. Higher real interest rates were an international phenomenon, reflecting a German reunification and a lower rate of inflation. But it was augmented in Sweden by weak confidence in the krona, a result of the country's relatively high rate of inflation in the 1980s. Real interest after tax also increased in Sweden as a result of a tax reform in 1990-1991, which included a reduction in progressive income taxes and tax allowances.

Swedish economic policy in the 1990s was shaped, not only by the deep recession at the beginning of the decade, but also by new rules of the game. In October 1990, after a large capital outflow from Sweden, the social democratic government announced a restrictive fiscal policy programme and that Sweden would apply for membership in the European Union. In May 1991, the social democratic government decided to tie the krona to the ECU. The government wanted to convince the actors in financial (and labour) markets that devaluations 
were ruled out. However, in the fall of 1992, the Central Bank failed to prevent a major outflow of capital from Sweden. The centre-right (four-party) government, installed in September 1991, decided, in consultation with the social democratic opposition, on two fiscal policy crisis packages to defend the krona. The crisis packages contained reduced payroll taxes to increase Sweden's competitive strength, but also sizeable budget increases. The defence of the krona failed, and in November 1992 Sweden abandoned the system of fixed exchange rates. In January 1993 the Central Bank settled a target of 2 per cent inflation with an allowed flexibility of 1 percentage point in either direction; the inflation taget began to apply from January 1995. The Central Bank had gradually become more independent from the mid-1980s; the formal decision of independence was taken in 1998 after a constitutional change. In addition, in the mid-1990s, Sweden adopted, as many other Western countries, strict rules for fiscal policy as recommended by the new consensus in economics. Farreaching deregulation, especially of product markets, in the 1990s was also in conformity with the new consensus. Sweden switched to a new, general, economic-policy regime in the 1990s although some deregulation had already taken place in the middle of the 1980s (see the deregulation of credit markets) and economic policy still contained Keynesian and R-M elements.

\subsection{The Rehn-Meidner programme under a new economic-policy regime}

High unemployment in the 1990s was an obvious Swedish departure from the goals of the RM model. What is more, after a steady decline in 1998-2001, the rate of unemployment began to rise again and was in 2006, despite an economic recovery, 7 percent with a standardised (ILO) measure and 5.3 per cent with a conventional (national) measure (OECD Economic Outlook, December, 2007, table 13 and 14). Thus, in the mid-2000s, Sweden no longer met the strong requirements of full employment in the R-M model. Furthermore, participation 
rates were still much lower than at the beginning of the 1990s. Neither was the goal of the social democratic government in 1998 to increase the employment share of the population aged 20-64 years to 80 percent before 2005 achieved. Labour force participation was not at stake when the R-M model was developed, but the decline in Swedish participation rates in the 1990s and 2000s, although from a high rate, was certainly a failure in light of the model. However, Swedish employment failures do not necessarily mean that policy makers had given up the high ambitions of full employment or abondened the mechanisms of the R-M model.

The non-socialist four-party government 1991-1994 used the concept of "the only way" to dissociate its economic policy from the third way of the social democrats. However, by opposing expansionary fiscal policy and devaluations to achieve low rates of unemployment, the only way was a continuation, although more explicitly, of a challenge to the Keynesian post-war model that had been started in the early 1980s and expanded under a social democratic government in the early 1990s. The attempts by a social democratic, and then by a non-socialist, government to raise confidence in the krona in the early 1990s was actually in accordance with the R-M policy of attaining price stability and enhancing economic growth. Consequently the Swedish abandonment of the system of fixed exchange rates, and the reduction of payroll taxes, might be looked upon as a dismantling of the R-M policy to fight inflation and stimulate growth. However, the inflation target for the Central Bank can simultaneously be seen as a device, in the spirit of the R-M model, to create a price-stabilizing framework for employment policy, and to maintain transformation pressure (see next section). 
Fiscal policy (for the whole public sector) was more expansionary in 1992 than the year before in spite of the intention of the non-socialist government to be restrictive. ${ }^{48}$ A large increase in the Swedish public deficit was the result both of a depression (through automatic stabilisers) and, more importantly, of a looser fiscal policy. Among other things, commercial banks were offered huge grants in the aftermath of the deep financial crisis. Despite crisis packages and the centre-left government's ambition to reduce the public budget deficit, fiscal policy (for the entire public sector) was still expansionary in 1993-1994 and not even tighter in 1993. Fiscal policy contributed significantly to a Swedish public budget deficit in 1993 that was larger than in all other OECD countries with the exception of Greece. Fiscal policy was then tightened in 1994 but Swedish fiscal policy was, although not deliberately, predominantly expansive and countercyclical during the non-socialist period 1991-1994.

The policy along the only way had failed in its chief task of creating confidence in the Swedish krona. By contributing to a budget deficit fiscal policy was an important reason for the currency crisis hitting Sweden in the fall of 1992. However, the absence of a contractionary fiscal policy during a deep recession with increasing unemployment was actually in accordance with the R-M model. Moreover, the only way of the non-socialist government showed, without any explicit reference, other similarities to the R-M programme. The government, like the R-M model, expressed scepticism concerning incomes policy. Furthermore deregulation of product markets along the one way, for example of telecommunications, postal services and passenger air traffic, was hardly any break with the R-M model giving priority to market conforming measures and to policies reducing profit margins. ${ }^{49}$ The non-socialist government also carried on an ambitious labour market policy

\footnotetext{
${ }^{48}$ Fiscal policy for the entire public sector was also countercyclical under a social democratic government during the dramatic downswing of 1991 (Braconier and Holden, 1999, fig. 5.2.5; OECD Economic Outlook June 2001, table 31 and June 2005, table 30).
} 
during the crisis. During the last years of the social democratic government, active labour market policy had in fact not been very active, despite increasing unemployment. Expenditure on labour market policy as a share of GDP rose considerably during the non-socialist government (see Table 1 in Appendix). ${ }^{50}$ The share of the labour force in active labour market programmes reached a post-war peak in 1994 (7.3 per cent).

The orientation of labour market policy under the non-socialist government was almost in full agreement with the R-M model. Supply and adjustment oriented measures increased significantly in 1992. The training share of total expenditures and participants in labour market policy was reduced during the last two years of non-socialist government when (public) relief work and the basically demand-oriented work experience schemes (ALU projects) and youth practice programmes were expanded. But supply and matching measures were still the most important part of active labour market policy. ${ }^{51}$ The government also introduced a universal (though temporary) system of employment subsidies in 1994. (The social democrats had in mid-1980s introduced a system of marginal recruitment grants, which was permanent though less general than the non-socialist proposal.)

Non-socialist employment policy measures might still have been too limited according to the R-M model. ${ }^{52}$ However the most serious challenge to the model in the 1990 s was to come from the social democrats. The social democratic government, taking over in September 1994,

\footnotetext{
${ }^{49}$ Decisions by the non-socialist government were the prime reason behind a radical deregulation of product markets in Sweden in the 1990s (Erlandsen and Lundsgaard, 2007).

${ }^{50}$ Spending on active labour market policy was also high in Sweden compared to other OECD countries in the first half of the 1990s, especially if adjusted for the rate of unemployment (Nickell, 1997, table 4; OECD Employment Outlook, various issues).

${ }^{51}$ Appendix 1. See also Johannesson, 1995, table 2.2; Ackum Agell, 1995, pp. 70-3; Statistics Sweden, 1998, table 306.
} 
was to implement the fiscal restraint that the non-socialist government had first applied the same year. ${ }^{53}$ The party that had pioneered the Keynesian revolution now introduced an extremely restrictive fiscal policy in a situation of mass unemployment. The social democratic fiscal restraint 1995-1998, with Göran Persson first as Minister of Finance (1994-1996) and then as Prime Minister, has no equivalent in other OECD countries in the period of comparative statistics from 1970 and onward. ${ }^{54}$ In 1998, the public budget deficit disappeared thanks to an international recovery and, above all, a tighter fiscal policy. Moreover, the Central Bank, governed by its inflation target, pursued tight monetary policy from 1995 until the beginning of 1997. Restrictive macroeconomic policy in a situation of mass unemployment was inconsistent, not only with Keynesianism, but also with the R-M model.

However, the social democratic Cabinet, like the previous non-socialist government, engaged in an ambitious labour market programme. In line with the priorities of the R-M model, public relief work became gradually less important from the mid-1980s until 2006. In 1996 and 1997, the demand-oriented ALU projects involved more people than the training programmes in labour market policy. This development could be seen as a deviation from the R-M programme in a situation of excess demand for highly skilled people in the Swedish economy (see particularly the IT-boom in Sweden in the late 1990s). But from 1998, participating in labour market training was again to dominate labour market policy, if programmes for handicapped people are excluded. The remarkable "Knowledge Boost" (Kunskapslyftet) 1997-

\footnotetext{
${ }^{52}$ Furthermore, cuts in taxes on capital by the non-socialist government were probably a break with the strong emphasis on equity in the R-M model.

${ }^{53}$ The restrictive policy of the social democrats was to a larger extent constituted by higher income taxes than the non-socialist government's only way. Employment had fallen drastically in the public sector in the years of the non-socialist government.The social democrats received support in Parliament for their fiscal restraint, first from Vänsterpartiet and then (from January 1995) from Centerpartiet. From Autumn 1998, they were supported by Vänsterpartiet and Miljöpartiet (the Green Party). ${ }^{54}$ Price and Muller, 1984, table 1; OECD Economic Outlook June 1997, 2001, table 31 and June 2005, table 30;
Braconier and Holden, 1999, pp. 24-7.
} 
2002, to increase the level of education and to reduce unemployment among adults with only grammar school education, was also in line with the supply-oriented R-M model. The programme engaged 10 percent of the labour force during the first four years (Albrecht et al., 2004, p. 1). The social democratic government had also introduced a form of temporary employment subsidy in 1995 - firms recruiting unemployed were given financial assistance. Furthermore, the increasing weight of employment subsidies in Swedish labour market policy since 1998 can be regarded as a late breakthrough for a crucial feature of the R-M model. In 1997, employment subsidy grants embraced only 1.9 per cent of all individuals engaged in labour market policy programmes financed by AMS and other public authorities. In 2005, this share had risen to 20.3 per cent. ${ }^{55}$

But the relation between the R-M model and the social democratic labour market policy from the mid-1990s was ambiguous. The share of the labour force engaged in labour market policy programmes steadily decreased until 2004. Swedish expenditures on labour market policy in proportion to GDP showed a similar decline. The weaker emphasis on labour market policy by the social democrats largely reflected better labour market conditions. But in 2000 expenditure on active labour market policy programmes as a share of GDP became lower in Sweden than in Denmark and the Netherlands, two countries with less unemployment than Sweden. ${ }^{56}$ It cannot be discounted that Sweden's lower ranking is explained by the increasing weight of employment policy measures under public authorities other than the AMS (see the "Knowledge Boost" in particular). However, the lower priority of AMS programmes meant that the government was not prepared to meet increasing unemployment in the early 2000 s or

\footnotetext{
${ }^{55}$ Statistics Sweden, 2005, table 356 and 2008, table 353, see also Appendix 1.

${ }^{56}$ See $O E C D$ Economic Outlook, various issues, Table H. Further, in the period 1999-2002, subsidies to regular employment in the private sector recommended by Rehn and Meidner were higher in Belgium, Italy and Spain than in Sweden as a share of GDP. This share was also approximately as high in Finland, France and Canada as in Sweden (OECD Employment Outlook 2004, table H).
} 
the slow employment recovery in the following export-led expansion. Furthermore, from the late 1990s, employment subsidy programmes, and also other labour market policy measures, have targeted long-term unemployed and older people, a clear break with the universal employment policy of the R-M model. ${ }^{57}$ Also the social democratic scheme of employment subsidies in 1995 could have been criticised on R-M grounds for its non-universal character, subsidies were paid to the unemployed only. (By being given also for the re-employed the subsidies were not even marginal.)

The relation between some labour market reforms from the mid-1990s and the R-M model was also ambiguous. In 1995 the social democratic government decided on further reductions in unemployment benefits; the replacement ratio was reduced from 80 to 75 per cent in January 1996. The non-socialist government had reduced the replacement ratio in 1993, from 90 to 80 per cent. The social democrats also made exceptions from the Job Security Act of 1974 by allowing short-time employment contracts (1996) and exclusion of two individuals in companies with fewer than 10 employees from the principle of last-in first-out (2001). The RM model seems to be compatible with the exceptions from the Job Security Act but not with the reductions of replacement ratios from the mid-1990s. However, the pre-1996 replacement rate (80 per cent) was restored in 1997, among other things as a result of a budget surplus for central government. Furthermore, a labour market reform in 2001-2002 satisfied the "flexicurity" principle of the R-M model. It intended not only to increase effective replacement rates but also to stimulate labour market flexibility by reductions of unemployment benefits over time. ${ }^{58}$ The benefit ceiling was raised though primarily for the first 20 weeks of unemployment. Recipients were allowed to restrict search to their

\footnotetext{
${ }^{57}$ Since 2000 training programmes have largely been substituted by special counselling and placement measures for long-term unemployed (aktivitetsgarantin). See Revised Budget Bill 2001, appendix 3, pp. 12-17.
} 
occupation and local labour market - which made the system more generous (at least in theory) - but only during the first 20 weeks of unemployment (Bennmarker et al. 2007, pp. 88-92).

An ambiguity attached to the relation between the R-M model and the macroeconomic policy of the social democrats after the consolidation of the public budget. The government introduced some disciplinary budget reforms, which can be seen as an unconscious application of the model. In 1995 the social democrats decided to introduce a ceiling for expenditures by central governments, effective from 1997. The ceiling covered all items in the national budget including social insurance (but excluding interest on the government debt). In addition, from 1997, the social democrats had a fiscal policy target that required the consolidated public budget to show a surplus of 2 percent of GDP over a business cycle. This budget reform was clearly in accordance with the R-M model. One motif for a public budget surplus over the business cycle was also in conformity with the R-M view - the surplus makes countercyclical fiscal policy possible without big budget deficits in a recession. ${ }^{59}$ Moreover, there are arguments for not putting forth strong objections to short-run macroeconomic policy in Sweden from the late 1990s, using the R-M model as a norm. Fiscal policy for the entire public sector was restrictive, though mainly countercyclical..$^{60}$ Neither was the direction of Swedish monetary policy from the late 1990s a serious challenge to the R-M model, considering that unemployment was still high in the country. In general the policy of the Central Bank was not only countercyclical during the first half of the 2000s, but also expansive from 1997 until 2006.

\footnotetext{
${ }^{58}$ Through a ceiling on earnings eligible for unemployment benefits, nominal wage growth in 1993-2000 had reduced the effective replacement ratios, especially for highly-paid workers (see Bennmarker et al., 2007, p. 90).

${ }^{59}$ Ministry of Finance, 2000, pp. 29-30. But the government did not formulate a R-M argument for public savings to replace savings in domestic enterprises for reasons of stabilisation, distribution and growth.
} 
However, a R-M criticism of the new economic policy in Sweden can still be directed towards the low employment aspirations in economic policy. It is doubtful whether the specific inflation target ( 2 per cent inflation) defined by the Central Bank is in agreement with the high employment ambitions of the R-M model (cf. Lundborg and Sacklén, 2006). Moreover, in 1996, the social democrats set up the same goal for unemployment as in fact the former non-socialist government - to reduce open unemployment (national measure) to 4 percent before 2000. The employment policy ambition of the social democrats was satisfied, but it was too modest to meet the strong demands of the R-M model. Hence it seems that the redefinition of full employment by Bertil Ohlin and Erik Lundberg in the early post-war years eventually won the day.

The social democratic abandonment of the goals of a very low rate of unemployment and the restrictive rules for macroeconomic policy were obvious challenges to Keynesianism. But incomes policy was reminiscent of the Keynesian post-war model in the new stabilisationpolicy regime of the 1990s (see also the countercyclical macroeconomic policy from the late 1990). In 1990, when the economy was still overheated, the social democratic government had put great trust in a mediation body, the Rehnberg Commission. The commission managed to bring about a coordination of wage negotiations for the period 1991-1993, including almost all central labour market organisations. In the mid-1990s, the social democrats again brought the idea of incomes policy onto the political agenda, after the non-socialist parenthesis. The government had plans for tripartite wage negotiations, plans that were hardly compatible with the R-M recommendation that the trade union movement should not take responsibility for the stability of the national economy, especially in a situation of high profits (see below). Further,

\footnotetext{
${ }^{60}$ See OECD Economic Outlook June 2005, table 30 and also von Hagen and Bruckner, 2002, pp. 140-3.
} 
the plans were inconsistent with the Swedish tradition of wage negotiations without government intervention dating from the late 1930s (the Saltsjöbaden Agreement). However, the government did not realise its plans for tripartite negotiations, but instead in 2000 set up a separate mediation institute.

In the first half of the 1990s, LO and other parties on the labour market, of their own initiative, had worked out a wage policy programme according to which wage increases on a Western European level would reduce long-term interest rates by lowering the risk premium. Such wage increases would also allow higher real wages through appreciations, once the confidence in the krona was increased, although ideally within limits to secure high profit shares (The Edin Group, 1995, pp. 33-4). However, LO became no part of coordinated wage negotiations in the second half of the 1990s and the early 2000s. A bargaining agreement between central labour market organisations in manufacturing, the so-called Industrial Agreement (Industriavtalet) was signed in 1997. Agreements have been settled for three-year periods stipulating wage moderation in order to keep up Swedish competitive strength in terms of relative unit labour costs and profit margins of the exposed sector. Negotiations take place under the whip of the explicit inflation targets for the Central Bank (cf. Carling et al., 2000 and Industrins Ekonomiska Råd, 2003). Today, the Industrial Agreement has counterparts in other sectors of the Swedish economy. The Agreement is expected to serve as guideline for wage negotiations outside manufacturing. In fact, since 1993, LO has persistently succeeded to coordinate wage claims for blue-collar trade unions. However wage coordination for individual sectors has restricted the possibility of a comprehensive wage policy of solidarity. Also, the Industrial Agreement has hitherto, if compared to the R-M recommendations, left greater emphasis on stabilisation than on distribution. Besides, there is no correspondance in the wage philosophy behind the Industrial Agreement to the R-M 
growth theory, in which high profit margins have a negative effect on productivity. The initiators of the agreements have also a greater faith than Rehn and Meidner in the ability of central labour market organisations to influence the general wage development, even in a situation of high profits.

An obvious challenge to the priorities of the R-M model was the further increase in wage dispersion in Sweden in the 1990s and 2000s. In the 1990s wage dispersion increased the most between industries and plants, compromising fairness in the terms of the original notion of solidaristic wages policy. ${ }^{61}$ As in other OECD countries there was also a continued increase in the dispersion of gross earnings between all workers in Sweden. From the mid-1990s to the mid 2000s wage differentials increased to a large extent between white-collar workers, and also between white-collar and blue-collar workers. ${ }^{62}$ However, despite growing wage gaps, Sweden was still, together with Norway, an OECD country of extensive earnings equalisation in the mid-2000s (OECD Employment Outlook, 2007, table H).

Another important departure from the R-M model during the 1990s and the first half of the 2000s was the tendency to higher profit margins and a higher profits share in the business sector. ${ }^{63}$ According to the model, high profit shares are undesirable from the viewpoint of income distribution; they also add fuel to the inflation process and restrict economic growth. In the first year of floating exchange rates (1993), the krona was depreciated by 25 percent against the currencies of competing countries. The depreciation explains, together with strong

\footnotetext{
${ }^{61}$ Hibbs and Locking, 2000, figure 1; Nordström Skans et al., 2006, table 1 and figure 3.

${ }^{62}$ Lundborg, 2005; Nordström Skans et al., 2006, table 1; Erixon, 2008, appendix 2.

${ }^{63}$ In fact, the increase in the profits share in manufacturing from the mid-1970s to the early 2000s was arguably stronger in Sweden, Finland and Canada than in other OECD countries (see Appendix 2). Moreover, effective tax rates on new investment were lower in Sweden than in most OECD countries in the mid-2000s (OECD, 2006, figure 2.1).
} 
productivity growth and higher rates of unemployment, why the profit share in Swedish manufacturing rose to higher levels in the mid-1990s (above 40 per cent) than ever before in the post-war period. (I disregard here the profit boom during the Korean War.) What is more, the profit share remained at a high level despite a falling rate of unemployment in 1998-2001. Profits were consolidated by continuing productivity increases, and by a weaker krona in 1996-2001 which particularly mitigated the profit fall in the recession of the early 2000s. Improved business-cycle conditions and continued strong productivity increases resulted in a new profit boom in 2005-2006. Higher unemployment compared to earlier decades was a salient structural condition for the upward shift in the profits share in Sweden during the 1990s and 2000s. ${ }^{64}$

\subsection{New circumstances for the Rehn-Meidner model}

In conclusion, the relationship between the economic and wages policy of the 1990s and 2000s and the R-M model is fraught with contradictions. There are signs that social democratic, as well as non-socialist, governments had taken over - without reference to the model - its basic idea of stabilisation; that full employment must be reached within the framework of a restrictive macroeconomic policy. Explicit inflation and budget targets, and also Central Bank independence, could be seen as price-stabilising frameworks for an active employment policy. Social democratic and non-socialist governments pinned their hopes on labour market policy in the 1990s, that is during a decade when theories of the limitations of interventionist economic policy received their definite breakthrough. It seems that an active employment policy had been institutionalised in Sweden in the post-war period making a

\footnotetext{
${ }^{64}$ There were further departures from the R-M model in the 1990s and the early years of the new millennium. In 1998, pension reform agreement between the social democratic government and the non-socialist opposition reduced the element of public saving in the Swedish social insurance system. In the mid-2000s, securities and shares owned by individuals, but administrated by a national authority (PPM), were responsible for more than half of total savings in the Swedish pension system (Ministry of Finance, Budget Bill 2005, table 4.18).
} 
challenge to this policy on either ideological or economic grounds a risky political project. However, the inflation target of the Central Bank was probably too demanding to satisfy the high employment ambitions of the R-M model. The restraining fiscal and monetary policy in the mid-1990s in a situation of mass unemployment was the clearest expression of a departure from the priorities and means of the R-M model. More targeted measures and less expenditure on labour market policy as a share of GDP from the mid-1990s, despite high, and, in the early 2000s, increasing unemployment were other violations of the ideas of Rehn and Meidner. A continuing wage spread in itself and a voluntary incomes policy without strong redistributive ambitions were further deviations from the R-M model in the 1990s and early 2000s. From the viewpoint of the model there was also an unwarranted boost in the profits share of GDP. But it remains to be explained why Sweden deviated from some goals and means of the R-M model in the period under review.

The deep recession of the early 1990s made it more difficult to bring down Swedish unemployment by labour market policy programmes.$^{65}$ Moreover, the depth, and also date, of the economic and financial crisis in Sweden, occurring in a period of turbulent global financial markets, explained the sudden change to and also maintenance of flexible exchange rates in the country. For example, Denmark and Norway, which experienced earlier and also milder economic crises than Sweden, chose to keep a system of fixed exchange rates (Danmark) or a system of flexible exchange-rate goals (Norway until 2001). The shift to flexible exchange rates in Sweden was critical for the R-M model since it reduced the possibility of predicting and controlling profits. From a R-M perspective, high profits through depreciations of the krona generated extensive wage drift and tendencies towards wage-wage

\footnotetext{
${ }^{65}$ However, the sheer volume of labour market policy and the postponement of a restrictive fiscal policy are salient reasons why open unemployment was kept lower in Sweden than in Finland that also had been plagued by a similar economic crisis in the early 1990s.
} 
spirals in the mid-1990s that were only checked by a high rate of unemployment. Furthermore, the change to flexible exchange rates had given fiscal policy - a strategic macroeconomic variable in the original R-M model - a subordinate role in stabilisation policy. The neutralisation of fiscal policy, hitting also the Keynesian post-war model, was accentuated by a continuing globalisation of financial markets and a complete abolition of Swedish currency controls in 1989.

The Swedish disappointment cycle hit the Keynesian post-war model rather than the R-M model in the early 1990s. The common view among leading politicians and economists was that devaluations and expansionary fiscal policy in the 1970s and the 1980s had maintained high employment with artificial respiration, exacerbated inflation and fostered a deep economic crisis. ${ }^{66}$ The negative review of Keynesian stabilisation policy in the 1970 s and 1980s was not completely fair. The rate of inflation in Sweden was only substantially higher than the OECD and EU total between 1988 and 1991. Moreover, with a benevolent interpretation, the Keynesian post-war model can be connected with measures to alleviate severe overheating. Furthermore, OECD estimates show that almost 40 per cent of the Swedish public deficit 1991-1994 reflected low activity levels rather than lax fiscal policies. ${ }^{67}$ But more important, the Swedish disappointment cycle in the first half of the 1990s did not primarily challenge the R-M model whose application had meant a tighter macroeconomic policy in the 1980s resulting in smaller public deficits in the first half of the 1990s. The model was also a point of reference for the Swedish Productivity Commission (1989-1991) which blamed Sweden's low growth rate in the 1980s on too a weak transformation pressure. The commission emphasised that the devaluations had delayed structural change and obstructed

\footnotetext{
${ }^{66}$ One argument was that the Keynesian "accommodation policy" had, by enhancing inflation expectations, resulted in a gap between Swedish and German long-term interest rates in 1990-1991. Analogously, politicians in all camps and their economic advisors maintained that the following Swedish public deficits contributed to a new gap between Swedish and German long-term interest rates in 1994-1995.
} 
the development and use of new products, technologies and work organisations in Swedish manufacturing (Erixon 1991; Swedish Productivity Commission, 1992). In fact, in her tenacious defence of a fixed krona, and also opposition to reduced payroll taxes, the Finance Minister of the non-socialist government, Anne Wibble, referred to the need for transformation pressure to increase economic growth (Swedish Economic Association, 1991, pp. 76-7).

This is not to say that the R-M model was not a target in the disappointment cycle of the early 1990s. Swedish economists began to criticise labour market policy on empirical grounds for being ineffective and inflationary (Erixon, 2000, pp. 66-9). The passive labour market policy of the social democrats in 1990-1991 was seen by some observers as a confirmation that the party had downgraded the priority of full employment and also espoused economists' critical view of active labour market policy (SOU 1993:43, pp. 38-9 and 47). This conclusion is controversial. The main reason for the modest size of active labour market policy measures in 1990-1991 was that the social democratic government was yet not aware of, or prepared to meet, the strong tendencies towards mass unemployment. ${ }^{68}$ On the other hand, evaluations of labour market policies by economists were one reason for why the social democrats, in conflict with the R-M model, put less emphasis from the mid-1990s on labour market policy and reallocated resources to older people and long-term unemployed to minimize deadweight and substitution (crowding-out) effects. Swedish economists had concluded that the positive

\footnotetext{
${ }^{67}$ OECD Economic Outlook 2007, no. 81, table 29 and 30.

${ }^{68}$ According to an influential argument, the social democratic government came to prioritise the struggle against inflation in 1990-1991, thus giving lower priority to full employment (cf. Lindbeck, 1997, p. 1303; Jonung, 1999 pp. 69-85; Holmlund, 2006). However, the argument is based on declarations by the government at the time when the Swedish economy was still overheated, or immediately after, when available information as to the depth of recession was still limited (Ministry of Finance, Budget Bill 1990, p. 12 and 1991, pp. 1-8). In fact, already in the 1950s and 1960s, social democratic governments had made a similar priority of the fight against inflation in the peaks.
} 
employment effects of extensive labour market policy programmes in the first half of the 1990s were either small or non-existent. ${ }^{69}$

The Swedish disappointment cycle in the 1990s was shaped by new economic theories about rational expectations and time-inconsistencies in political decision-making. The new economic ideas challenged the Keynesian post-war model, and in some respect, also the R-M model. In the mid-1980s leading Swedish politicians and their economic-policy advisors were influenced by "norm economics", a Swedish version of the new ("neo-monetarist") consensus in economics, although they had already accepted the new ideas in the early 1980s. Norm economists emphasised the negative experiences of Swedish "accommodation policies" and the need for measures to reduce inflation expectations in the country by strengthening confidence in fixed rates of exchange (cf. Tson Söderström et al., 1985 and Jakobsson, 2000, pp. 124-7). Their attitude to the R-M model was ambiguous. Some norm economists saw the R-M stabilisation policy at the beginning of the 1970s as worthy of imitation (Tson Söderström et al., 1985, pp. 36-7). They also underlined by references to the Swedish Productivity Commission, the need for transformation pressure when opposing new devaluations and reductions of payroll taxes in the early 1990s (Tson Söderström et al., 1992, pp. 13-4 and 49-53). The similarities between norm policy and the R-M model, however, should not overshadow the fact that the norm economists were critical of coordinated wage bargaining and of state interventionism regarding economic policy, a criticism that also hit labour market policy. ${ }^{70}$

\footnotetext{
${ }^{69}$ Blanchflower et al., 1995; Forslund and Krueger, 1997; Calmfors, et al., 2001; Sianesi, 2002.

${ }^{70}$ Tson Söderström et al., 1985, pp. 97-8 and 128-9. Also, by supporting a transfer of resources from the public to the private sector, essentially the open one, most Swedish neo-monetarists had no "structural" objections to the devaluations of the 1970s and 1980s. Their main criticism of the social democratic devaluation in 1982 was that the following fiscal spending policy was not restrictive enough to guarantee a transfer of resources to the private sector (Jonung, 1991, pp. 14 and 32). In spite of the devaluations, general government's share of total employment actually increased in Sweden in the 1980s.
} 
In the mid-1990s, economic experts working for the new social democratic government began to refer to the NAIRU and "natural" (equilibrium) rate of unemployment, central notions of new macroeconomics. They agreed with leading academic economists that the equilibrium rate of unemployment in Sweden was above the actual rate (approximately 2 per cent) at the end of the 1980s, and also increasing during this decade because of higher replacement ratios and less wage coordination. Furthermore, officials in the Ministry of Finance shared the OECD view that the equilibrium rate of unemployment had increased (for unclear reasons) in the first half of the 1990s. ${ }^{71}$ The social democrats therefore accepted unemployment rates above 3 per cent and the need for structural reforms in the labour market to reduce equilibrium unemployment. However, the reduction of the replacement rate in the unemployment insurance system in the mid-1990s was primarily a part of the budget consolidation policy (Ministry of Finance, Revised Budget Bill 1995, p. 31).

There is no obvious distance between the R-M model and the concepts of NAIRU and equilibrium unemployment in modern economics (see Erixon, 2008). But the model's tradeoff between unemployment and inflation except under overheated conditions accords better with a partial rehabilitation than with an absolute rejection of the Phillips curve (cf. Akerlof et al., 2000 and Lundborg and Sacklén, 2006). The emphasis on price stability as a superior objective of economic policy in modern macroeconomics was a breach of the R-M model. Furthermore, new bargaining theory provided a challenge to the R-M theory in which market forces are fundamental in wage formation and incomes policy could be harmful for economic growth. Swedish economic-policy advisers began to use "wage-setting" models to demonstrate that equilibrium unemployment could be reduced by responsible trade unions 
and by corporate arrangements such as the Industrial Agreement (cf. Layard et al., 1991 and National Institute for Economic Research, 2004, pp. 18-19).

Swedish economic policy in the 1990s and 2000s is also explained by economic-policy fallacies. In fact some political failures supported the Keynesian post-war model and the R-M model rather than the new economic paradigm. The four-party, non-socialist government 1991-1994 was too divided to embark on a fiscal policy along its own only way until 1994; thus, in a situation of high unemployment, the non-socialists were "neo-monetarists" in theory but Keynesians in practice. The decision by the following social democratic government to pursue an expansionary fiscal policy before the elections in 1998, 2002 and 2006 seemed a threat not only to the self-imposed budget goals of the government, but also to the disciplinary economic policy of the R-M model. ${ }^{72}$ However, during these years, unemployment was still high in Sweden, and 2002 was a clear recession year, probably legitimating expansionary fiscal measures from the viewpoint of the R-M model. On the other hand some economicpolicy fallacies were unfavourable to the priorities of the model. Incorrect predictions of employment and inflation developments during the first half of the 2000s made labour market policy less active and Central Bank's policy less expansionary than could be expected from the social democrats' employment goals and the Central Bank's inflation target respectively. The rate of inflation was, as in the second half of the 1990s, systematically below the target 2

\footnotetext{
${ }^{71}$ Ministry of Finance, Revised Budget Bill 1995, appendix 1.1, p. 91 and Budget Bill, 1996, appendix 1, p. 38.

${ }^{72}$ Some examples of a procyclical fiscal policy under the social democratic government, even after the mid1990s, reflected an accounting-book view of fiscal policy - the government declared that improvements in the budget balance provided room for welfare reforms and for compensation to low-income groups for earlier fiscal restraints (Ministry of Finance, Budget Bill 1998, pp. 19-20; Revised Budget Bill 1998, pp. 27-8, 1999, p. 24 and 2000, p. 19 and 2001, pp. 19-20). Both election and accounting-book considerations explain (together with strong pressure from LO) the decisions by the social democrats in the election year of 1998 to reduce income taxes and increase public expenditures, for example by rising replacement rates to their pre-1995 level leading to fiscal expansion in 1999.
} 
per cent and fell occasionally below the lower limit of 1 per cent (Giavazzi and Mishkin, 2006, pp. 50, 77 and 98).

The victory for a new economic paradigm in Sweden during the 1990s, departing in some pivotal respects from the R-M model, confirms the strong influence of professional economists on Swedish economic policy. While in opposition the social democrats had criticized, as in the early 1980s, a non-socialist government for making the fight against inflation a priority, and for its unwillingness to see low domestic demand as the main problem of the Swedish economy. As late as January 1994, the party issued a proposal in Parliament for a Keynesian programme of private investment stimuli and government purchases. But the fiscal policy of the social democrats in power from September 1994 was governed by the view among experts in the Ministry of Finance, shared by the Minister of Finance Göran Persson, that the party needed to achieve the fiscal restraint that the non-socialist government had neither the strength nor political support to fully realize. ${ }^{73}$

A stronger position for LO over economic policy in the 1990s and 2000s would probably have resulted in unemployment rates more in accordance with the strict claims for full employment in the R-M model. The change in power relations during these decades was unfavourable to central trade unions in general and to LO in particular. The degree of unionisation was still high in the country but it decreased steadily after a peak in the mid1990s, from 86 per cent 1995 to 77 per cent 2006 (Nelander and Lönnros, 2000, table 2 and diagram 8; Kjellberg, 2007). In addition the bargaining position of labour was weakened by a higher rate of unemployment. Moreover SAF's categorical refusals to participate in coordinated wage bargaining, and in other corporatist arrangements, around 1990 had 
weakened LO's influence on wage policy and also on economic policy (see Martin, 2000). Furthermore, LO had lost influence on Swedish economic policy through its Keynesian standpoint. However, an argument that globalisation had weakened the position of LO (and of Swedish labour in general) is contradicted by the fact that foreign production by Swedish companies did not increase in relation to their exports from Sweden during the 1990s (Ekholm and Hesselman, 2000, pp. 9-11).

A R-M policy of wage solidarity was prevented in the 1990s and 2000s by continued industrial agreements and by the fact that redistribution was given lower priority than earlier in central bargaining. The room for solidarity wages policy was also reduced in Sweden during these decades through a strong tendency to local agreements between companies on the one hand, and local trade unions and individual workers on the other. In the second half of the 1990s, the wage system was more decentralised in Sweden than in Finland, Germany, Ireland, Italy and the Netherlands (Nickell et al, 2005, table 3). To a large extent, wider wage gaps within plants and between all workers in the 1990s and 2000s reflected structural changes in the labour market. A global shift in labour demand through the third industrial revolution favoured skilled labour, particularly computer specialists and R\&D personnel (cf. Gustavsson, 2007). In the absence of extensive training and educational programmes, which could have stimulated the supply of skilled labour, wage gaps increased considerably in Sweden in favour of some white-collar workers in the 1990s. During the second half of the 1990s and the early 2000s the Swedish tendency to larger earnings inequality in the top half of the distribution also appeared in other OECD countries specialising in ICT industries or with a large share of ICT-related occupations (see OECD, 2007, pp. 129-131 and Erixon,

\footnotetext{
${ }^{73}$ The non-socialist government had to rely on the support in Parliament from a right-wing populistic party ( $N y$ Demokrati).
} 
2008). A R-M explanation of the larger wage inequalities in Sweden from the mid-1990s is the increase in profits, especially in the exposed sector. ${ }^{74}$

EU integration had consequences for Swedish economic policy in the 1990s and 2000s. Already in 1992, a non-socialist government had reduced the VAT, not primarily to counter the recession but to adjust to the tax profile of the EU countries. Furthermore, Swedish governments of all colours felt obliged to adhere to the convergence rules of the Maastricht Treaty of 1991. The ambition of the social democrats to meet the Maastricht convergence criteria had been strengthened by the party's participation in the campaign for membership of the EU, and by Sweden joining the Union in 1995 after a referendum the previous year. Preparing for membership in the European Monetary Union the social democratic government also felt compelled to follow the Stability and Growth Pact of $1997 .^{75}$

It is difficult to draw unambiguous conclusions regarding the status of the R-M model in an increasingly politically integrated Europe. The requirements of the EU Stability and Growth Pact of 1997 for the member countries' public budgets to be in balance or even show a surplus over the economic cycle, are in conformity with the model. Moreover the Maastricht convergence rule excluded large fluctuations in exchange rates and therefore in profits. Certain aspects of the EU project contradict the R-M model. Both the Maastricht convergence rules and the original Stability and Growth Pact forbid public budget deficits larger than 3 per cent of GDP. Countries with a large public sector will have difficulties meeting the budget deficit constraint imposed by the Pact even if some deviations were permitted in the case of deep recessions; restrictive fiscal policies may even be necessary to counteract tendencies

\footnotetext{
${ }^{74}$ Higher profits in the 1990s may have led to larger wage differentials between plants and between firms in Sweden through a rent-sharing mechanism (see Arai and Heyman, 2004) but also, as emphasised in the R-M model, through increasing financial opportunities to compete for scarce labour. Moreover, an enlarged financial capacity to compete for skilled labour might have resulted in larger wage gaps within plants and firms.
} 
toward large public budget deficits, unleashed by low economic activity, through automatic stabilisers. A strict application of the rules of the Stability and Growth Pact in Sweden would, therefore, be incompatible with the high employment ambitions of the R-M model. Restrictive fiscal policy in Sweden in the mid-1990s satisfied the EU criteria for budget discipline (and for the size of the public debt) but it was hardly compatible with the R-M model.

EU integration contributed to the breakthrough of the new consensus about economic policy in Sweden but its impact on Swedish economic policy should not be exaggerated. A similar economic policy was also conducted in countries not restricted by EU rules for macroeconomic policy. It seems that the argument for an adjustment to the EU were used by leading politicians and their economic experts in Sweden to legitimate economic-policy reforms and measures considered as inevitable against the background of new insights in economics and the country's history of high inflation. Moreover, Sweden is still outside the EMU - a referendum in 2003 clearly rejected a Swedish participation.

\section{A summary}

This paper has analysed the application of a unique model of economic and wage policy in Sweden, the R-M model, and also used the model as a point of departure for a survey of Swedish economic policy in the post-war period. The typical Swedish model was never consistently and consciously implemented. Yet, the 1960s and early 1970s must be seen as the golden age of the R-M model; the model legitimised and contributed strongly to the expansion of labour market policy and the practice of the wages policy of solidarity. Furthermore this period witnessed an increase in public saving, a decline in the profits share of GDP and an introduction of indirect taxes. It is possible to disentangle some unique

\footnotetext{
${ }^{75}$ Ministry of Finance, 1995; Budget Bill 1998, appendix 2, pp. 6-7 and Budget Bill 2000, p. 22.
} 
Swedish circumstances behind the application of the R-M model - the strong position for state interventionism, the political dominance of the social democrats, the innovative character of the R-M ideas, and the strength and priorities of LO. Swedish deviations from the model since the middle of the 1970s are explained by negative policy experiences, a weaker position and new strategy of LO, a new generation of economic-policy decision makers, new economic theories (challenging discretionary economic policy), the growing influence of professional economists and by macroeconomic policy failures. The break with the R-M model is also explained by political-institutional changes, primarily deregulation of credit markets (leading to overheating in the 1980s), new exchange-rate systems from the mid-1970s (providing more space for profit booms through devaluations/depreciations) and less coordinated wage bargaining (threatening the wage policy of solidarity). It cannot be excluded, however, that departures from the R-M model are basically explained by economicstructural conditions. Increasing internationalisation of financial markets and large companies has undoubtetly weakened the position of trade unions and narrowed the room for policy measures squeezing profits in Sweden. The IT revolution and high demand for IT skilled labour have certainly contributed to widening wage gaps in the country. Furthermore, the definition of identical jobs - a centrepiece of the solidarity wages policy - has probably been complicated by the introduction of new technologies and work organisations favouring more decentralised and individualised wage negotiations.

However this paper has played down the importance of globalisation and new technological paradigms, and also of EU integration, for Swedish deviations from the R-M model. The model was shaped by Sweden's position as a small open economy and the early foreign orientation of Swedish companies. By arguing for deregulation, labour-market flexibility, retraining and structural change the model was also largely unrelated to the technology and 
industrial composition of the early post-war period. Moreover there is no clear evidence of a conflict between foreign production and export by Swedish multinational companies in the post-war period. A conjecture that the departure from central wage coordination is an inevitable consequence of the "crisis of fordism" is weakened by the fact that there is no general tendency towards less wage coordination in countries specialised in ICT products. Furthermore, Swedish experiences since the mid-1980s show that more decentralised and individualised wage bargaining has not excluded tacit agreements among LO unions, nor the emergence of new institutions for wage coordination. However this paper has not addressed the specific question whether globalisation and technical change has made the R-M model obsolete.

Swedish economic policy since the mid-1970s can be classified as a hybrid of a Keynesian, R-M and "neo-monetarist" model in which active labour market policies are the recurrent RM features (see Erixon, 2008, appendix 1). The combination of labour market policies (including employment subsidies) with strict rules for monetary and fiscal policy since the early 1990s is, at least in principle, compatible with the R-M model. Perhaps paradoxical for a foreign observer, Sweden has been able to attain higher productivity growth and lower inflation rates than most other OECD countries but not to maintain the low rates of unemployment or the small wage differentials of the 1970s and 1980s. Yet the application of the R-M model has contributed to a situation in which low rates of unemployment and small wage gaps have been institutionalised in Sweden. The social democrats, that is the active agents behind the early Keynesian revolution and the implementation of the R-M ideas in Sweden, were defeated in the election in 2006 since they had contributed to, but failed to meet, the high employment ambitions of the "Swedish model". 


\section{Literature}

Ackum Agell, S. (1995). 'Swedish labour market programs: efficiency and timing', Swedish Economic Policy Review, vol. 2, no. 1, pp. 65-98.

Akerlof, G.A., Dickens, W.T. and Perry, G.L. (2000). 'Near-rational wage and price-setting and the long-run Phillips curve', Brookings Papers on Economic Activity, vol. 1, pp. 1-44.

Albrecht, J., van den Berg, G. and Vroman, S. (2004). 'The knowledge lift: The Swedish adult education program that aimed to eliminate low worker skill levels', Working Paper 2004:17, Uppsala, Institute for Labour Market Policy Evaluation (IFAU)

Arai, M. (1994). 'An empirical analysis of wage dispersion and efficiency wages', Scandinavian Journal of Economics, vol. 96, no. 1, pp. 31-50.

Arai, M. (1999). 'Wages, profits and capital intensity: evidence from matched worker-firm data', Research Papers in Economics 1999:3, Stockholm, Department of Economics, Stockholm University

Arbetarrörelsens efterkrigsprogram - de 27 punkterna med motivering (1944). Stockholm: Victor Pettersons Bokindustriaktiebolag.

Baker D., Glyn, A, Howell D. and Schmitt, J. (2005). 'Labor Market Institutions and Unemployment: A Critical Assessment of the Cross-Country Evidence', in (D.R. Howell, ed.) Fighting Unemployment: The Limits of Free Market Orthodoxy, chapter 3, New York: Oxford University Press.

Bennmarker, H., Carling, K. and Holmlund, B. (2007). 'Do benefit hikes damage job finding? Evidence from Swedish unemployment insurance reforms', Labour, vol. 21, no. 1, pp. 85120.

Bergström, H. (1987). Rivstart? Om övergången från opposition till regering, Stockholm: Tidens Förlag.

Beveridge, W. H. (1944). Full Employment in a Free Society, London: George Allen \& Unwin Ltd.

Bjørnson Barkby, B. (2000). 'Koordinering av inntektsoppjørene i Norge og Sverige 19611999', Arbeidsnotat 3/2000, Oslo: Ragnar Frisch Centre for Economic Research.

Blanchflower, D.G., Jackman, R. and Saint-Paul, G. (1995). Some reflections on Swedish labour market policy, Report to the Committee on Swedish Labour Market Policy, SOU 1995:39E, Stockholm, Fritzes

Braconier, H. and Holden, S. (1999). 'The public budget balance - fiscal indicators and cyclical sensivity in the Nordic countries', The National Institute of Economic Research, Stockholm and Department of Economics, Oslo, mimeo.

Calmfors, L. (1993). 'Lessons from the macroeconomic experience of Sweden', European Journal of Political Economy', vol. 9, no. 1, pp. 25-72. 
Calmfors, L., Forslund, A. and Hemström, M. (2001). 'Does active labour market policy work? Lessons from the Swedish experiences', Swedish Economic Policy Review, vol. 8, no. 2, pp. 61-124.

Carling, A., Djerf, O., Kazamaki-Ottersten, Eugenia and Ohlsson, H. (2000). 'Industriavtalet -utfall och framtidsutsikter', Ekonomisk Debatt, vol. 28, no. 5, pp. 417-430.

Carlsson, B. (1983). 'Det svenska industristödet i internationell jämförelse', Ekonomisk Debatt, vol. 11, no. 7, pp. 466-476.

D’Agostino, H. (1987). 'Arbetarförbundens medlemsutveckling i Sverige 1900-1985', Report 9/1987, Stockholm: Swedish Institute for Social Research.

The Edin Group (1995). 'I takt med Europa - samhällsekonomiska aspekter på lönebildningen', A report from Arbetsgivareverket, Kommunal, Kommunförbundet, Landstingsförbundet, LO, Metall, SACO, SAF, SIF and TCO. Stockholm: LO, mimeo.

Edvinsson, R. (2005). Growth Accumulation Crisis - With New Macroeconomic Data for Sweden 1800-2000, Stockholm Studies in Economic History 41, Stockholm: Almqvist \& Wiksell International.

Ekholm, K. and Hesselman, M. (2000). 'The Foreign Operations of Swedish Manufacturing Firms: Evidence from a Survey of Swedish Multinationals 1998', Working Paper no. 540, Stockholm: The Research Institute of Industrial Economics (IUI).

Erixon, L. (1985). 'What's wrong with the Swedish model? An analysis of its effects and changed conditions 1974-1985', Report 12/1985, Stockholm: Swedish Institute for Social Research.

Erixon, L. (1987). Profitability in Swedish Manufacturing - Trends and Explanations, Stockholm: Almqvist \& Wiksell International.

Erixon, L. (1988). 'Löner och konkurrenskraft - lönekostnadernas betydelse för Sveriges världsmarknadsandelar', SIND PM 1988:5, Stockholm: National Industrial Board (SIND).

Erixon, L. (1989). 'Den tredje vägen - inlåsning eller förnyelse?', Ekonomisk Debatt, vol. 17, no. 3, pp. 181-95.

Erixon, L. (1991). 'Omvandlingstryck och produktivitet', in Konkurrens, regleringar och produktivitet, Expert report no. 7 to the Swedish Productivity Commission, Stockholm: Allmänna Förlaget.

Erixon, L. (1994). Investeringar och lönsamhet, Expert report no. 7 to the Medium Term Survey, Stockholm: Fritzes.

Erixon, L. (1997). 'The golden age of the Swedish model', Report 97:9, Oslo: Institute for Social Research. 
Erixon, L. (2000). The 'Third Way' Revisited. A Revaluation of the Swedish Model in the Light of Modern Economics, Stockholm: Trade Union Institute for Economic Research (FIEF).

Erixon L. (2001). 'A Swedish economic policy - the theory, application and validity of the Rehn-Meidner model', in (H. Milner and E. Wadensjö, eds.) Gösta Rehn - At Home and Abroad, London: Ashgate Ltd.

Erixon, L. (2004). 'A 'third way' in economic policy: a reppraisal of the Rehn-Meidner model in the light of modern economics', in (P. Arestis and M. Sawyer, eds.) Neo-liberal Economic Policy - Critical Essays, Cheltenham, UK: Edward Elgar Ltd. Revised version of article with the same title in International Papers in Political Economy, vol. 9 (2), 2002.

Erixon, L. (2008). 'The Swedish third way - assessment of the performance and validity of the Rehn-Meidner model', Cambridge Journal of Economics, forthcoming.

Erlander, T. (1976). 1955-1960, Stockholm: Tidens Förlag.

Erlandsen, E. and Lundsgaard, J. (2007). 'How regulatory reforms in Sweden have boosted productivity', OECD Economics Department Working Papers no. 577, Paris: OECD.

Faxén, K-O (1989). 'Några kommentarer till SAFs lönepolitiska uttalanden under 1920-talet', in Vingarnas trygghet - arbetsmarknad, ekonomi och politik, Lund: Dialogos AB, pp. 69-75.

Feldt, K.O., 1991. Alla dessa dagar - i regeringen 1982-1990. Stockholm: Norstedts.

Forslund, A. and Krueger, A. B. (1997). 'An evaluation of the Swedish active labour market policy: new and received wisdom', in (R.B. Freeman, R. Topel, and B. Swedenborg, eds.) The Welfare State in Transition - Reforming the Swedish Model, Chicago and London: The University of Chicago Press.

Frank, N., Ohlsson, H. and Vredin, A. (1993). 'Systematik och autonomi i finanspolitiken', in K-G Löfgren and L-E Öller, eds.) Konjunkturprognoser \& konjunkturpolitik, Ekonomiska Rådets Årsbok 1992, Stockholm: National Institute for Economic Research (Konjunkturinstitutet).

Giavazzi, F. and Mishkin, F.S. (2006). An Evaluation of Swedish Monetary Policy Between 1995 and 2005, Report from the Swedish Parliament, 2006/07:RFR1, Stockholm,:The Committee on Finance.

Gustavsson, M. (2007). 'The 1990s rise in Swedish earnings inequality - persistent or transitory?', Applied Economics, vol. 39, no.1§, pp. 25-30.

Von Hagen, J. and Bruckner, M. (2002). 'Monetary and fiscal policy in the European Monetary Union', Monetary and Economic Studies, special edition December, pp. 123-165.

Hansen, B. and Rehn, G. (1956). 'On wage-drift. A problem of money-wage dynamics', in 25 Economic Essays in Honour of Erik Lindahl, Stockholm: Ekonomisk Tidskrift. 
Hibbs, D.A. Jr. (1990). 'Wage dispersion and trade union action in Sweden', in I. PerssonTanimura (ed) Generating Equality in Sweden, Oslo, Scandinavian University Press.

Hibbs, D.A. Jr. and Locking, H. (2000). 'Wage dispersion and productive efficiency: evidence for Sweden', Journal of Labor Economics, vol. 18, no. 4, pp. 755-782.

Holmlund, B. (1997). 'Some new evidence on wage behaviour in Sweden', in Elvander, N. and Holmlund, B. (eds) The Swedish Bargaining System in the Melting Pot-Institutions, Norms and Outcomes in the 1990s, Stockholm, The Swedish Center for Work Life Research

Holmlund, B. 2006. The rise and fall of Swedish unemployment, in Werding, M. (ed), Structural Unemployment in Western Europe: Reasons and Remedies, Cambridge, MA, MIT Press

Holmlund, B. and Zetterberg, J. (1991). 'Insider effects in wage determination - evidence from five countries', European Economic Review, vol. 35 (5), pp. 1009-1034.

Hoeller, P., Louppe, M-O., and Vergriete, P. (1996). 'Fiscal relations within the European Union', Economics Department Working paper No. 163, OECD, Paris.

Industrins Ekonomiska Råd (2003). Industriavtalet - köpkraft och konkurrenskraft, En rapport till Industrikommittén av Industrins Ekonomiska Råd, Stockholm

Jakobsson, U. (2000), 'Makropolitik i Sverige', in (B. Södersten, ed.), Marknad och politik, Stockholm: The Industrial Council for Social and Economic Studies (SNS Förlag).

Jakobsson, U. and Herin, J. (1981), '1970-talets stabiliseringspolitik', Skandinaviska Enskilda Banken Kvartalsskrift, vol. 53, no. 3-4, pp. 40-51.

Johannesson, J. (1981). 'On the composition of Swedish labour market policy', The Expert Group for Labour Market Research (EFA), Stockholm: Ministry of Labour.

Johannesson, J. (1991). On the Outcome of Swedish Labour Market Policy, The Expertgroup for Labour Market Policy Evaluation Studies (EFA), Stockholm: Ministry of Labour.

Johannesson, J. (1995). 'Labour market policy as an economic-political instrument', in (J. Johannesson and E. Wadensjö, eds.) Labour Market Policy at the Crossroads, EFA, Stockholm: Ministry of Labour.

Jonung, L. (1993). 'Riksbankens politik 1945-1990', in Från räntereglering till inflationsnorm - det finansiella systemet och riksbankens politik 1945-1990. Stockholm: The Industrial Council for Social and Economic Studies (SNS Förlag).

Jonung, L. (1991). 'Rivstart eller snedtändning', in (L. Jonung, ed.) Devalveringen 1982 rivstart eller snedtändning - perspektiv på svensk devalveringspolitik, Stockholm: The Industrial Council for Social and Economic Studies (SNS Förlag).

Jonung, L. (1999). Med backspegeln som kompass - om stabiliseringspolitiken som läroprocess. Rapport till Expertgruppen för studier i offentlig ekonomi, Ds 1999:9. 
Stockholm: The Department of Finance. An English summary, 'Looking Ahead Through the Rear-View Mirror. Swedish Stabilisation Policy 1975-1995. A Summary’.

Jonung, L. (2000). 'Från guldmyntfot till inflationsmål - svensk stabiliseringspolitik under det 20:e seklet', Ekonomisk Debatt, vol. 28, no. 1, pp. 17-32.

Kjellberg, A. (1983). Facklig organisering i tolv länder, Lund: Arkiv Förlag.

Kjellberg, A. (2000). 'The multitude of challenges facing Swedish trade unions', in (J. Waddington and R. Hoffman, eds.) Trade Unions in Europe - Facing Challenges and Searching for Solutions, Brussels: European Trade Union Institute (ETUI).

Kjellberg, A. (2007). 'Det fackliga medlemsraset i Sverige oktober 2006 - oktober 2007: en första översikt', Department of Sociology, Lunds university, Working paper, December 2007.

LO (1953). Trade Unions and Full Employment. Report to the LO Congress 1951, Stockholm: The Swedish Confederation of Trade Unions (LO). First published in Swedish in 1951.

LO (1984). Den produktiva rättvisan, Stockholm: Tiden.

LO-tidningen (1989). Interview with Dan Andersson, no. 49, December 8.

Layard, R., Nickell, S. and Jackman, R. (1991). Unemployment - Macroeconomic Performance and the Labour Market, Oxford University Press, Oxford.

Lindbeck, A. (1975). Svensk ekonomisk politik, Malmö: Aldus.

Lindbeck, A. (1976). 'Dynamisk företagsamhet förutsätter hyggliga vinster', Ekonomisk Debatt, vol. 4, no. 2, pp. 123-124.

Lindbeck, A. (1997). 'The Swedish experiment', Journal of Economic Literature, vol. 35, no. 3, pp. 1273-1319.

Lindvall, J. (2004). The Politics of Purpose - Swedish Macroeconomic Policy after the Golden Age, Gothenburg: Department of Political Science, Gothenburg University.

Lundberg E. (1952a). 'General survey of some issues of wage policy', in (R. Turvey, ed.) Wages Policy Under Full Employment, London: William Hodge and Company.

Lundberg E. (1952b). 'A critique of Rehn's approach', in (R. Turvey, ed.) Wages Policy Under Full Employment, London: William Hodge and Company.

Lundberg, E. (1972). 'Productivity and structural change - a policy issue in Sweden', The Economic Journal, vol. 82, no. 325, pp. 465-485.

Lundberg, E. (1981). 'Gunnar Strängs ekonomiska filosofi - personliga iakttagelser och erfarenheter', in En bok om och till Gunnar Sträng, Stockholm: Tidens Förlag, pp. 91-115. 
Lundberg, E. (1985). 'The rise and fall of the Swedish model', Journal of Economic Literature, vol. 23, no. 1, pp. 1-36.

Lundborg, P. (2005). 'Individual wage setting, wage gaps and productivity', Stockholm: Trade Union Institute for Economic Research (FIEF), mimeo.

Lundborg, P. and Sacklén, H. (2006). 'Low-inflation targeting and long-run

Unemployment', Scandinavian Journal of Economics, vol. 108, no. 3, 397-418.

Lundh, C. (2002). Spelets regler. Institutioner och lönebildning på den svenska arbetsmarknaden 1850-2000, Stockholm: The Industrial Council for Social and Economic Studies (SNS Förlag).

Martin, A. (2000). The politics of macroeconomic policy and wage negotiations in Sweden', in (T. Iversen, J. Pontusson and Soslice, D., eds.) Unions, Employers, and Central Banks, Cambridge: Cambridge University Press.

Matthiessen, L. (1971). 'Finanspolitiken som stabiliseringspolitiskt instrument', in Svensk finanspolitik i teori och praktik, Stockholm: Aldus/Bonniers.

Medium Term Survey (1980). Långtidsutredningen 1980 SOU 1980:52, Stockholm: Ministry of Economics.

Meidner R. (1952). 'The dilemma of wages policy under full employment', in (R. Turvey, ed.) Wages Policy Under Full Employment, London: William Hodge and Company Ltd. Revised version of 'Lönepolitikens dilemma vid full sysselsättning', Tiden, 1948, vol. 40, no. 9.

Meidner, R. (1969). 'The goals of labour market policy', in On Incomes Policy, Paper and Proceedings from a Conference in Honour of Erik Lundberg, Stockholm: The Industrial Council for Social and Economic Studies (SNS Förlag).

Meidner, R. (1974). Samordning och solidarisk lönepolitik, Stockholm: The Swedish Confederation of Trade Unions (LO).

Meidner, R. (1988). 'Gösta Rehn as an LO economist', Journal of Economic and Industrial Democracy, vol. 9, no. 4, pp. 455-474.

Ministry of Finance (1995). 'Konvergensprogram för Sverige', June 1995. Stockholm: The Ministry of Finance, mimeo.

Ministry of Finance (2000). 'Finans- och penningpolitiskt beslut för 1990-talet', Appendix 5 to the Budget Bill 2000/01:100.

Ministry of Finance, Budget Bills of Sweden, periodical.

National Institute for Economic Research (2004). Lönebildningen. Samhällsekonomiska förutsättningar i Sverige 2004. Stockholm: National Institute for Economic Research (Konjunkturinstitutet). 
Nelander, S. and Lönnroos, E. (2000). Facklig organisationsgrad. LO, Löne- och välfärdsenheten, Stockholm: LO.

Nickell, S. (1997). 'Unemployment and labour market rigidities: Europe versus North America', The Journal of Economic Perspectives, vol. 11, no. 3, pp. 55-74

Nickell, S., Nunziata, L. and Ochel, W. (2005). 'Unemployment in the OECD since the 1960s. What do we know?', The Economic Journal, vol. 115, no. 1, pp. 1-27.

Nilsson, C. (1995). Den interregionala omflyttningen $i$ Sverige, Stockholm: EFA Arbetsdepartementet.

Nordström Skans, O., Edin, P.A. and Holmlund, B. (2006). 'Wage dispersion between and within plants: Sweden 1985-2000', Workings Papers 2006:9, Uppsala, Institute for Labour Market Policy Evaluation (IFAU)

OECD. Economic Outlook, periodical, Paris: OECD.

OECD. Employment Outlook, periodical, Paris: OECD.

OECD. National Accounts of OECD Countries, Volume II, periodica, Paris: OECD.

OECD. Historical Statistics 1960-1986, Paris: OECD.

OECD (1987). OECD Economic Surveys 1986/1987 - Sweden, April 1987, Paris: OECD.

OECD (2006). OECD Economic Surveys - Canada, Paris: OECD.

OECD (2007). OECD Science, Technology and Industry Scoreboard 2007, Paris: OECD.

Ohlin, B. (1949). 'Aspects of the economics of over-full employment', in The Problem of Employment Stabilization, New York: Columbia University Press.

Ohlsson, I. (1980). 'Den solidariska lönepolitikens resultat', in Lönepolitik och solidaritet. Stockholm: The Swedish Confederation of Trade Unions (LO).

Öhman, B. (1974). LO och arbetsmarknadspolitiken efter andra världskriget, Stockholm: Prisma and LO.

Price, R. W.R. and Muller, P. (1984). 'Structural budget indicators and the interpretation of fiscal policy stance in OECD economies', OECD Economic Studies No. 3, Autumn 1984. Paris: OECD.

Rehn, G. (1952a). 'The problem of stability: an analysis and some policy proposals', in (R. Turvey, ed.) Wages Policy Under Full Employment, London: William Hodge and Company Ltd. Revised version of 'Ekonomisk politik under full sysselsättning', Tiden, 1948, vol. 40, no. 3 .

Rehn, G. (1952b). 'A reply to professor Lundberg', in (R. Turvey, ed.) Wages Policy Under Full Employment, London: William Hodge and Company Ltd. Revised version of 
'Lönepolitiken och fullsysselsättningen. Replik till professor Lundberg', Ekonomisk Tidskrift, 1950, vol. 52, no. 1 .

Rehn, G. (1969). 'The relationship between productivity development and the state of overall demand' and 'Labour market policy and the 'Rehn Model', Discussions in On Incomes Policy, Paper and Proceedings from a Conference in Honour of Erik Lundberg, Stockholm: The Industrial Council for Social and Economic Studies (SNS Förlag).

Rehn, G. (1977). 'Finansministrarna, LO-ekonomerna och arbetsmarknadspolitiken', in Ekonomisk Debatt och ekonomisk politik - Nationalekonomiska föreningen 100 år, Stockholm: Norstedts.

Rehn, G. (1982). 'Anti-inflationary expansion policies (with special reference to marginal employment premiums)', Report to the Commission of the European Communities. Occasional Paper No. 4. Brussels: Commission of the European Communities.

Rehn, G. (1987). 'State, economic policy and industrial relations in the 1980s: problems and trends', Economic and Industrial Democracy, vol. 8, no. 1, pp. 61-79.

Rehn, G. (1993). 'Socialdemokratin inför verkligheten', Stockholm, mimeo.

Scharpf, F. (2000). 'The viability of advanced welfare states in the international

economy: vulnerabilities and options', Journal of European Public Policy, 7, no. 2, 190-228.

Sianesi, B. (2002). 'Differential effects of Swedish active labour market programmes for unemployed adults during the 1990s', Working Paper 2002:5, Uppsala, Institute for Labour Market Policy Evaluation (IFAU)

Södersten, J. (1971). 'Företagsbeskattning och resursfördelning', in (E. Lundberg, ed.) Svensk finanspolitik i teori och praktik, Stockholm: Aldus/EFI.

Södersten, J. and Lindberg, T. (1983). 'Skatt på bolagskapital - Sverige i jämförelse med Storbritannien, USA och Västtyskland', Forskningsrapport $n r$ 20. Stockholm: The Swedish Institute for Economic and Social Research (IUI).

SOU 1982:27. Svensk industri i utlandet - en analys av drivkrafter och effecter. Expertrapport från Direktinvesteringskommittén. Stockholm: Allmänna Förlaget.

SOU 1993:43. Politik mot arbetslöshet. Report from the Expert Group for Labour Market Policy Evaluation Studies (EFA). Stockholm: Allmänna Förlaget.

Statistics Sweden (2005 and 2008). Statistical Yearbook of Sweden, Stockholm: Statistics Sweden.

Summers, L. H. (1986). 'Why is the unemployment rate so very high near full employment?', Brookings Paper on Economic Activity, no. 2, pp. 339-383.

Swedenborg, B., Johansson-Grahn, G. and Kinnwall, M. (1988). Den svenska industrins utlandsinvesteringar 1960-1986, Stockholm: Industriens Utredningsinstitut. 
Swedenborg, B. (2001). 'Determinants and effects of multinational growth - the Swedish case revisited', in (M. Blomström and L. Goldberg, eds.) Topics in Empirical International Economics - A Festschrift in Honor of Robert E. Lipsey, Chicago and London: The University of Chicago Press.

Swedish Economic Association (Nationalekonomiska föreningen) (1968). Nationalekonomiska föreningens förhandlingar, årets statsverksproposition, Nationalekonomiska föreningens sammanträde den 16 januari 1968, Stockholm: Haglund \& Ericson Boktryckeri AB.

Swedish Economic Association (Nationalekonomiska föreningen) (1972). Nationalekonomiska föreningens förhandlingar, årets statsverksproposition, Nationalekonomiska föreningens sammanträde den 12 januari 1972, Stockholm: Haglund \& Ericson Boktryckeri AB.

Swedish Economic Association (Nationalekonomiska föreningen) (1992). Ekonomisk Debatt, vol. 20, no. 1, pp.76-93.

Swedish Government (1996). 'Government Proposition 1995/96:25', En politik för arbete, trygghet och utveckling. Stockholm: Fritzes.

Swedish Productivity Commission (1992). Forces of Productivity and Prosperity, Summary of SOU 1991:92, Stockholm: Allmänna Förlaget.

Swenson, P. and Pontusson, J. (2000). 'The Swedish employer offensive against centralized wage bargaining', in (T. Iversen, J. Pontusson and Soslice, D., eds.) Unions, Employers, and Central Banks, Cambridge: Cambridge University Press.

Tson Söderström, H. (1990). 'Stabiliseringspolitiska lärdomar och framtidsperspektiv', in (B. Södersten, ed.) Marknad och politik, Lund: Dialogos.

Tson Söderström, H. et al. (1985), 'Vägen till ett stabilare Sverige', Konjunkturrådets rapport 1985, Stockholm: The Industrial Council for Social and Economic Studies (SNS Förlag).

Tson Söderström, H. et al. (1992). Tillväxt utan gränser, Konjunkturrådets rapport 1992, Stockholm: The Industrial Council for Social and Economic Studies (SNS Förlag).

Viktorov, I. (2007), Fordismens kris och löntagarfonder i Sverige, Stockholm Studies in Economic History, series 51, Stockholm: Stockholm University.

Visser, J. (1992). Union Organization: Why Countries Differ, Sydney: IIRA.

Wallerstein, M. and Golden, M. (2000), 'Postwar wage setting in the Nordic countries', in (T. Iversen, J. Pontusson and Soslice, D., eds.) Unions, Employers, and Central Banks, Cambridge: Cambridge University Press.

Wadensjö, E. (2001). 'The labour market policy - Rehn or Rubbestad?', in (H. Milner and Wadensjö, E., eds.) The Swedish Model and Labour Market Policies - International and National Perspectives, Aldershot: Ashgate. 
Zweimuller, J. and Barth, E. (1994). 'Bargaining structure, wage determination, and wage dispersion in 6 OECD countries', Kyklos, vol. 47, pp. 81-93.

\section{Appendix}

Table 1: $\quad$ Swedish labour market policy 1965-2003. Expenditures by the National Labour Market Board (AMS) on active labour policy measures of various kinds, less regional policy measures. Expenditures on labour market policy by AMS as a share of GDP and by AMS and other public authorities as a share of GDP (in brackets).

\begin{tabular}{|c|c|c|c|c|c|c|c|}
\hline Year & Matching & Training & Job creation & Employment subsidies & Programs for disabled & Others & $\%$ of GDP \\
\hline 1965 & $12.1^{1}$ & 16.4 & 61.6 & - & 7.6 & 2.3 & 0.9 \\
\hline 1966 & $13.5^{1}$ & 20.1 & 55.3 & - & 9.0 & 2.1 & 0.8 \\
\hline $67 / 68$ & $11.6^{1}$ & 25.8 & 52.4 & - & 8.6 & 1.6 & 1.2 \\
\hline $68 / 69$ & $11.8^{1}$ & 25.3 & 51.0 & - & 10.6 & 1.3 & 1.4 \\
\hline $69 / 70$ & $15.6^{1}$ & 28.9 & 41.1 & - & 12.7 & 1.7 & 1.2 \\
\hline $70 / 71$ & 13.9 & 30.8 & 36.2 & - & 17.0 & 2.1 & $1.1(1.5)$ \\
\hline $71 / 72$ & 9.9 & 23.8 & 52.6 & - & 12.5 & 1.2 & $1.8(2.3)$ \\
\hline $72 / 73$ & 9.5 & 22.3 & 55.5 & - & 11.9 & 0.8 & $2.1(2.8)$ \\
\hline $73 / 74$ & 10.9 & 25.5 & 47.3 & - & 15.6 & 0.7 & $1.6(2.2)$ \\
\hline $74 / 75$ & 13.4 & 27.0 & 35.9 & - & 22.7 & 1.0 & $1.2(1.7)$ \\
\hline $75 / 76$ & 13.3 & 24.8 & 37.8 & - & 23.3 & 0.8 & $1.4(1.9)$ \\
\hline $76 / 77$ & 9.0 & 27.6 & 45.3 & - & 17.5 & 0.6 & $2.1(2.7)$ \\
\hline $77 / 78$ & 8.5 & 29.1 & 46.8 & $-{ }^{2}$ & 15.1 & 0.5 & $2.6(3.3)$ \\
\hline $78 / 79$ & 9.4 & 36.0 & 38.0 & $-{ }^{2}$ & 15.9 & 0.7 & $2.4(3.1)$ \\
\hline $79 / 80$ & 10.1 & 37.0 & 33.9 & $-{ }^{2}$ & 18.2 & 0.8 & $2.2(2.9)$ \\
\hline $80 / 81$ & 11.2 & 33.9 & 32.3 & $-{ }^{2}$ & 21.8 & 0.8 & $1.8(2.6)$ \\
\hline $81 / 82$ & 11.2 & 32.9 & 31.5 & $-{ }^{2}$ & 23.4 & 1.0 & $1.9(2.7)$ \\
\hline $82 / 83$ & 9.4 & 29.5 & 39.5 & $-{ }^{2}$ & 21.1 & 0.5 & $2.1(3.0)$ \\
\hline $83 / 84$ & 9.1 & 26.6 & 44.2 & $-{ }^{2}$ & 19.9 & 0.2 & $2.2(3.3)$ \\
\hline $84 / 85$ & 9.7 & 24.4 & 36.8 & 8.2 & 20.7 & 0.2 & $2.1(3.1)$ \\
\hline $85 / 86$ & 13.3 & 27.9 & 31.3 & 4.6 & 22.8 & 0.1 & $2.0(2.9)$ \\
\hline $87 / 88$ & 13.5 & 35.2 & 20.0 & 2.8 & 28.3 & 0.2 & $1.7(2.5)$ \\
\hline $88 / 89$ & 13.7 & 37.1 & 16.5 & 2.2 & 30.4 & 0.2 & $1.6(2.2)$ \\
\hline $89 / 90$ & 15.5 & 35.7 & 11.8 & 1.7 & 35.1 & 0.2 & $1.4(2.1)$ \\
\hline
\end{tabular}




\begin{tabular}{rrrrrrrr}
\hline $90 / 91^{3}$ & 12.4 & 31.4 & 10.7 & 1.2 & 43.8 & 0.5 & $(1.6)$ \\
$91 / 92^{3}$ & 8.5 & 41.1 & 12.6 & 3.7 & 33.7 & 0.4 & $(2.5)$ \\
$92 / 93^{3}$ & 8.1 & 35.5 & 23.0 & 5.5 & 27.9 & - & $(3.1)$ \\
$93 / 94^{3}$ & 8.4 & 25.5 & 32.3 & 7.4 & 26.5 & - & $(3.0)$ \\
$94 / 95^{3}$ & 9.0 & 25.8 & 28.8 & 9.0 & 27.4 & - & $(3.0)$ \\
$95 / 96^{3}$ & 11.0 & 23.3 & 22.0 & 13.6 & 30.0 & 0.1 & $(2.4)$ \\
$1997^{3}$ & 14.4 & 20.6 & 24.9 & 9.6 & 30.0 & 0.5 & $(2.1)$ \\
$1998^{3}$ & 14.3 & 23.0 & 25.5 & 7.1 & 30.1 & - & $(2.0)$ \\
$1999^{3}$ & 16.3 & 26.5 & 16.9 & 9.4 & 31.0 & - & $(1.8)$ \\
$2000^{3}$ & 21.9 & 21.2 & 10.2 & 10.2 & 36.5 & - & $(1.4)$ \\
$2001^{3}$ & 25.3 & 21.5 & 5.0 & 12.9 & 35.4 & - & $(1.4)$ \\
$2002^{3}$ & 15.3 & 29.5 & 11.7 & 12.3 & 30.7 & 0.5 & $(1.6)$ \\
$2003^{3}$ & 19.5 & 18.8 & 13.3 & 11.8 & 36.2 & 0.4 & $(1.3)$ \\
$2004^{3}$ & 19.2 & 16.0 & 12.0 & 15.3 & 34.7 & 2.8 & $(1.3)$ \\
$2005^{3}$ & 17.4 & 15.2 & 12.9 & 18.2 & 33.4 & 2.9 & $(1.3)$
\end{tabular}

Sources: Johannesson (1981, Table A.1), (1991, Table 1 A) and (1995, Table 2.1), Statistics Sweden and OECD Employment Outlook.

\section{Definitions:}

Matching activities include labour market information, geographical mobility and investigation costs. Training includes labour market education organized by AMS. Job creation measures include youth teams, in-plant training to avoid lay-offs, trainee replacement scheme (though not financed by AMS), orders and other supports to industries, introduction places, measures for partial unemployment, specific job creation programs, stockpiling subsidies, special job-design programs, relief work and trainee programs. Programs for disabled persons include special work-adjustment measures, vocational rehabilitation and public sheltered work. The category Other includes defence activities, procurement and administration of equipment and contributions from the European social fund.

${ }^{1}$ The share is underestimated. Some expenditure on labour information and regional mobility are counted as labour market training. On the other hand, the inclusion of expenditures on geographical mobility in the matching category throughout the table is doubtful. Thus there are two arguments why the first two columns should be added to achieve total expenditures on supply and adjustment oriented measures.

${ }^{2}$ Recruitment subsidies are included in the category job creation or excluded from the table by their regional nature.

${ }^{3}$ Estimates of the composition of labour market policy for these years is based on OECD Employment Outlook (see also the labour market policy share of GDP in brackets). These statistics cover expenditure not only by AMS but also by other public authorites. 
Table 2: Trends in gross profits share of gross value added in manufacturing, 10 OECD countries 1955-2003, average annual \% changes
$1955-2003$
$1955-1972$
$1973-2003$

\begin{tabular}{|c|c|c|c|}
\hline \multirow[t]{2}{*}{ Sweden } & 0.04 & -0.68 & 0.47 \\
\hline & $(0.26)$ & $(-9.30)$ & $(3.14)$ \\
\hline \multirow[t]{2}{*}{ Norway (1) } & 0.12 & 0.57 & 0.18 \\
\hline & $(3.70)$ & $(1.59)$ & $(3.61)$ \\
\hline \multirow[t]{2}{*}{ Finland (1) } & 0.23 & -0.55 & 0.51 \\
\hline & $(2.23)$ & $(-1.90)$ & $(4.94)$ \\
\hline \multirow[t]{2}{*}{ Denmark } & -0.11 & -0.57 & 0.25 \\
\hline & $(-0.40)$ & $(-1.61)$ & $(3.95)$ \\
\hline \multirow[t]{2}{*}{ Netherlands } & -0.10 & -0.37 & 0.05 \\
\hline & $(-0.28)$ & $(-0.92)$ & $(0.1)$ \\
\hline \multirow[t]{2}{*}{ Germany (2) } & -0.30 & -0.54 & -0.11 \\
\hline & $(-3.17)$ & $(-3.52)$ & $(-1.07)$ \\
\hline \multirow[t]{2}{*}{ United Kingdom } & 0.03 & -0.37 & 0.29 \\
\hline & $(0.25)$ & $(-18.21)$ & $(3.10)$ \\
\hline \multirow[t]{2}{*}{ USA } & 0.12 & 0.02 & 0.13 \\
\hline & $(5.0)$ & $(0.19)$ & $(5.0)$ \\
\hline \multirow[t]{2}{*}{ Canada (3) } & 0.13 & -0.15 & 0.61 \\
\hline & $(3.74)$ & $(-4.45)$ & $(3.65)$ \\
\hline \multirow[t]{2}{*}{ Japan } & -0.69 & 0.01 & -0.56 \\
\hline & $(-7.58)$ & $(0.09)$ & $(-4.64)$ \\
\hline
\end{tabular}

Source: Eurostat, OECD National Accounts Vol. II and National Statistics

1) Initial year 1960. 2) West Germany 1955-1990. 3) Final year 2001. T-stastistics in brackets.

Note: Source: Eurostat, OECD National Accounts Vol. II and National Statistics

1) Initial year 1960. 2) West Germany 1955-1990. 3) Final year 2001. T-stastistics in brackets.

Note: The augmented Dickey-Fuller (ADF) test was used to decide whether the time series of annual profit shares are nonstationary. The regression equations included a constant and a trend term. The augmented test was based on equations generally including two lagged first differences of the profit variables. Test statistics have been compared to the MacKinnon critical values for rejecting the hypothesis of a unit root on the 5 and 10 percent levels. In the cases of a rejection, the first differences of the profit variables were regressed on a constant, representing the stochastic time trend. In the cases where the ADF-tests were unable to reject the hypothesis of a unit root, deterministic trends were estimated from an equation with the profit share as a dependent variable and a constant and a trend term as independent variables. These estimates were based on an ARIMA specification. 